\title{
GEOCHRONOLOGY AND GEOMORPHOLOGY OF THE PIONEER ARCHAEOLOGICAL SITE (10BT676), UPPER SNAKE RIVER PLAIN, IDAHO
}

Joshua L. Keene

Month 2005

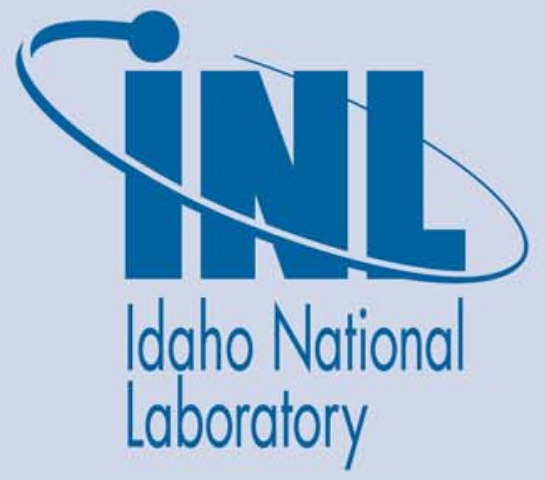

The INL is a U.S. Department of Energy National Laboratory operated by Battelle Energy Alliance 


\section{GEOCHRONOLOGY AND GEOMORPHOLOGY OF THE PIONEER ARCHAEOLOGICAL SITE (10BT676), UPPER SNAKE RIVER PLAIN, IDAHO}

Joshua L. Keene

April 2015

Idaho National Laboratory

Idaho Falls, Idaho 83415

http://www.inl.gov

Prepared for the

U.S. Department of Energy

Office of Nuclear Energy

Under DOE Idaho Operations Office

Contract DE-AC07-05ID14517 
Geochronology and Geomorphology of the Pioneer Archaeological Site (10BT676), Upper Snake River Plain, Idaho

By Joshua L. Keene

Texas A\&M University, College Station, TX

jlkeene@tamu.edu

Keywords: Snake River Plain, Idaho, Site Formation, Geochronology, Alluvial geomorphology 


\begin{abstract}
The Pioneer site in southeastern Idaho, an open-air, stratified, multi-component archaeological locality on the upper Snake River Plain, provides an ideal situation for understanding the geomorphic history of the Big Lost River drainage system. We conducted a block excavation to understand the geochronological context of both cultural and geomorphological components at the site. The results of this study show a sequence of multiple depositional episodes forming three terraces beginning prior to $7200 \mathrm{cal} \mathrm{yr}$ BP and lasting until the historic period, preserving one cultural component dated to $\sim 3800$ cal yr BP and multiple components dating to the last $800 \mathrm{cal}$ yr BP. Additionally, periods of deposition and stability at Pioneer indicate climate fluctuations during the middle Holocene ( 7200-3800 cal yr BP), minimal deposition during the late Holocene, and a period of increased deposition potentially linked to the Little Ice Age. In addition, evidence for a high-energy erosional event dated to 3800 cal yr BP suggests a catastrophic flood occurred during the middle Holocene that may correlate with volcanic activity at the Craters of the Moon lava fields to the northwest. This study provides a model for studying alluvial terraces in arid environments and their potential to preserve stratified archaeological deposits.
\end{abstract}




\section{INTRODUCTION}

The aridity of the Desert West poses a challenge to understanding chronological contexts of archaeological sites, as it has lead, in particular, to an overwhelming occurrence of unstratified surface assemblages (Beck \& Jones, 1997). While attempts have been made to date surface assemblages using chronologically sensitive projectile point styles (e.g. Thomas, 1981) or obsidian-hydration analysis (e.g., Tuohy, 1980; Hull, 2001; Rogers \& Duke, 2011), at best these methods only provide general ages, making it difficult to interpret any but the most basic trends in technological and cultural variation through time.

Assemblages from intact, buried contexts provide the most precise chronological controls, and though relatively rare, such sites in the Great Basin come almost exclusively from cave and rockshelter settings (eg. Jennings, 1957; Aikens, 1970; Thomas et al., 1983; Graf, 2007; Jenkins et al., 2012). However, in addition to being uncommon, these sites often have complex or mixed stratigraphy due to rockfall, bioturbation, and modern looting. Moreover, an over-reliance on rockshelters biases the archaeological record in favor of a specific site type and geologic/geographic setting.

While open-air sites in the Intermountain West more often than not tend to be surfacepalimpsests (Beck \& Jones, 1997), it is not uncommon for sites to be occasionally found in stratified contexts. While multiple-component, stratified sites are preferred since they can provide a look at diachronic change at a single locale, the most common of these tend to be single-component (or mixed component) sites capped by relatively thin layers of eolian sediments, often within dune formations, or beneath redeposited tephra (e.g., O'Connell, 1975; Raven \& Elston, 1989; Oetting, 1989; Jenkins, 1994; Mehringer \& Cannon, 1994; Oetting, 1994a; Oetting, 1994b; Simms, 1999; Kelly, 1999; Wingard, 1999; Bonstead, 2000; Galm \& 
Gough, 2001; Wriston, 2003; Pinson, 2004; O'Neill, 2004; Helzer, 2004; Madsen, 2005). These sites tend to have minimal vegetation cover, and are prone to wind erosion, meaning that most lack continuous deposition over long periods of time and may still represent palimpsests in cases were components were exposed for long periods before being buried. Multi-component, stratified sites are occasionally found within stratified eolian deposits as well (Rusco \& Davis, 1987; Mehringer \& Cannon, 1994; Dugas et al., 1995; Connolly, 1999; Jenkins, Droz \& Connolly, 2004; Moessner, 2004; Jenkins, 2004), but are still potentially prone to the same issues of site preservation.

Alluvial deposits in arid environments are also problematic for site preservation, as alluvial activity in such settings is usually marked by abrupt transitions from long-term dry conditions to high-energy flood events which carve out arroyos and erode cultural deposits (Waters, 1991) or form rapidly anastomosing braided-stream systems, jumbling archaeological deposits. Artifacts found within high-energy, laterally accreted bar and streambed deposits typically occur in secondary contexts, as in the deep layers of the Sunshine locality in Nevada where camel bones were redeposited with Paleoarchaic artifacts within gravelly channel deposits (Huckleberry, 2001; Beck \& Jones, 2009). Alluvial fans are another potential source for buried sites in the Great Basin, but these too are prone to mixing through braided flash-flood events and colluvial activity, in addition to rapid formation potentially burying sites under 10s-100s of meters of sediment in a relatively short time (Huckleberry, 2001).

Despite these issues, alluvial contexts are still the most ideal for the preservation of multi-component archaeological sites. In particular, vertically accreted overbank flood deposits tend to bury archaeological horizons gradually without redepositing artifacts (Waters, 1992:138; Huckleberry, 2001; Goebel, Waters \& Dikova, 2003), as seen at a few multi-component open-air 
sites in the Intermountain West (Irwin \& Moody, 1978; Rusco, 1987; Davis \& Rusco, 1987; Aikens \& Greenspan, 1988; Hicks, 2004; Davis \& Schweger, 2004), though even in these cases, most still have problematic radiocarbon chronologies.

A similar situation exists in the upper Snake River Plain region of southern Idaho, which, if not part of the hydrographic Great Basin, is ecologically and geomorphologically similar to the Great Basin directly to the south. Most multi-component, stratified sites are found in rockshelters or caves (i.e. Gruhn, 1961; Swanson \& Sneed, 1971; Miller, 1972; Miller, 1982; Lohse, 1989; Henrikson, 2003; Gruhn, 2006). While a few multi-component open-air sites also occur, primarily in alluvial settings (Swanson, Butler \& Bonnichsen, 1964; Powers, 1966; Swanson \& Dayley, 1968; Green, 1972; Plew \& Woods, 1985; Holmer \& Ringe, 1986; Lohse, 1994; Green et al., 1998; Schneider, 2002; Davis, 2005), nearly all of these occur on the periphery of the Snake River Plain in the foothills and not in the open desert (though see Holmer \& Ringe, 1986). In addition, very few open or rockshelter sites are reliably dated using current geoarchaeological or radiocarbon methods. Recent studies at the Pioneer site, however, provide a rare opportunity in the arid west to study an intact, open-air, multi-component archaeological site in a buried alluvial context in the open desert, in addition to providing a context to better understand late Quaternary geomorphology of the region.

The Pioneer site (10BT676) is a Holocene-age open-air site located along the Big Lost River in the Snake River Plain in southern Idaho on land managed by the Idaho National Laboratory (INL). Despite its location in a high-elevation, sagebrush-steppe environment, over two meters of low-energy alluvial deposition during the past 7000 years (cal yr BP) provide an ideal geochronological context for investigating Holocene site-formation processes and huntergatherer subsistence and mobility. The Pioneer site has also provided a dated context chronicling 
a series of geomorphological and paleoecological events in the Pioneer Basin following the early/middle Holocene transition. Of particular interest is a period of rapid erosion and increased river discharge around $3800 \mathrm{cal}$ yr BP, greater than any known flood for the area since the Pleistocene. By identifying and dating paleosol formations within alluvial terraces along the Big Lost River, we can generate a model for identifying relevant alluvial landforms for preserving open-air archaeological sites on the Snake River Plain.

Geomorphological and Archaeological Context

The Pioneer Basin, as originally defined by Nace and colleagues $(1956 ; 1975)$ and Butler (1968), is a hydrographic basin located on the northern boundary of the eastern Snake River Plain of southern Idaho. This basin consists of a series of sinks fed primarily by the Big Lost River, Little Lost River, and Birch Creek, as well as Crooked, Camas, and Medicine Lodge creeks, all of which flow from alluvial valleys of central Idaho's Basin and Range province to the northwest (Figure 1). Early archaeological and geomorphological studies in this area focused on high-profile archaeological sites along Birch Creek to the north (Swanson, Butler \& Bonnichsen, 1964; Swanson \& Sneed, 1971; Swanson, 1972) and at the Wasden site to the east (Butler, 1968; Butler, 1972; Miller, 1982). More recent geomorphological and hydrologic research relates to the development of facilities at the Naval Reactor Test Station, now known as the Idaho National Laboratory, a 2,225 $\mathrm{km}^{2}$ nuclear-reactor testing and environmental laboratory, which encompasses the bulk of the Pioneer Basin (Nace, Deutsch \& Voegeli, 1956; Nace et al., 1975; Bright \& Davis, 1982; Ostenaa et al., 1999; Ostenaa \& O'Connell, 2005).

Initial geomorphological studies by Nace and colleagues (1956) identified a series of sinks and ephemeral playas (prior to the historic diversion of water for irrigation in the early 
1900s) representing remnants of a once extensive, shallow lake known as Lake Terreton (Figure 1). At its furthest extent, this lake covered an area of $\sim 90 \mathrm{~km}^{2}$ and included modern-day Mud Lake, but it never reached a depth greater than 8 meters at its highstand around 1460 masl. While cores indicate that Lake Terreton fluctuated greatly during the Pleistocene (Gianniny et al., 1997; Geslin, Link \& Fanning, 1999), it is still unknown when it receded to the current boundaries of Mud Lake. A freshwater-shell date suggests that Lake Terreton may have existed as recently as $710 \pm 70{ }^{14} \mathrm{C}$ BP $(545-761$ cal yr BP) (Bright \& Davis, 1982), though issues with wind transport and shell dating bring this into question, and Ostenaa and colleagues (1999) suggest the shell was probably transported from a nearby active playa.

In addition to Lake Terreton, geomorphological studies have focused on the Big Lost River floodplain (Nace, Deutsch \& Voegeli, 1956; Nace et al., 1975; Rathburn, 1993; Gianniny et al., 1997; Ostenaa et al., 1999; Knudsen et al., 2002; Ostenaa \& O'Connell, 2005), an alluvial plain accompanying the largest river in the Pioneer basin. Upon reaching the Pioneer basin, the Big Lost River takes on a meandering form when not constricted by canyons and basaltic lava flows, with output decreasing significantly downstream due to infiltration into the Snake River Plain aquifer. Early studies (Nace, Deutsch \& Voegeli, 1956; Butler, 1968; 1975) described a series of gravelly terraces surrounding abandoned braided and anastomosing channels, with Nace et al. (1975) describing three alluvial terraces, providing relative ages for each based on the degree of weathering. Nace et al. (1975) assumed the least degraded braided channels were very recent, while the oldest terraces, marked by the presence of Mima-mound-like formations on the surface (Tullis, 1995), were oldest, dating to the Pleistocene. However, the large extent and thickness of these braided deposits indicate that they likely formed as a result of catastrophic floods, the last of which occurred either 20,000 (Cerling, Poreda \& Rathburn, 1994) or 50,000 
(Knudsen et al., 2002) cal yr BP. Ostenaa and O'Connell (2005) performed a GIS-based hydrologic/geomorphological study using high-resolution aerial photography combined with backhoe trenching to map the Big Lost River's terrace sequence. In addition to clarifying the distribution of the previously mentioned Pleistocene gravel bars, the authors identified a series of $\sim 1-3$ m high terraces composed of sandy and silty overbank flood deposits, which they interpreted to have formed as early as the Pleistocene/Holocene transition and then sporadically throughout the Holocene.

Ostenaa and O'Connell's (2005) study is by far the most comprehensive for the lower Big Lost River and has provided a strong basis for much of the terrace identifications used in this study. However, the geochronology of these events is still problematic. Ostenaa and O'Connell (2005) reported 16 radiocarbon dates (Table 1) on organic material from bulk sediment samples removed from four backhoe trench profiles transecting the Big Lost River. While five correlating dates from three trenches provide a somewhat reliable age estimate for flooding and terrace formation 400-600 years ago (i.e., the "400-year flood"), most other dates were from disturbed or unreliable contexts. Three ages acquired on materials from below the 400 -year flood horizon in trench T6 were reversed, ranging from $\sim 12,000$ to $\sim 2800 \mathrm{cal}$ yr BP. In trench T4, two dates from the same sample were nearly 1000 years apart, and in trench T9 two samples from $30-100 \mathrm{~cm}$ below the surface were practically modern. A single age of 7320-7200 cal yr BP from trench T4 potentially correlates to an early flood event stratigraphically below the 400 -year flood horizon, but unfortunately none of the geological trenches were excavated deep enough to clearly expose this deposit. Five remaining ages range between 2780-930 cal yr BP and suggest a long period of stability pre-dating the 400 -year flood, though these ages provide only an upper-limiting age for 
the formation of this surface. As a result, Ostenaa and O'Connell's (2005) chronology of terrace formation covers only the last 1000-2000 years, with few specific paleosols defined.

The Pioneer Archaeological Site

The Pioneer archaeological site was initially recorded in the 1980s as a large-scale, highdensity surface artifact scatter indicative of a prehistoric residential site. Cultural remains occurred in an area stretching more than $1 \mathrm{~km}$ along the Big Lost River (Figure 1) and contained a mix of diagnostic early to late Holocene bifacial points as well as protohistoric and historic debris, the latter resulting from its proximity to the Oregon Short Line (later Union Pacific) railroad grade. In addition, Goodale's Cutoff, an extension of the Oregon Trail, passed through the southern section of the Pioneer site, where remnants of the early 1900s Pioneer ghost town (Gilbert et al., 2009) are concentrated. Initial sub-surface testing by an Idaho State University field school in 2005 revealed a deep stratigraphic sequence with deeply buried archaeological material that was suspected to have spanned the Holocene.

Favorable geomorphic conditions for site preservation combined with the high density of archaeological artifacts dating back to Folsom times in the area surrounding Pioneer led INL archaeologists and me to organize a geoarchaeological project at Pioneer in 2010, aimed at revealing extensive stratified deposits with multiple paleosols and buried occupation surfaces with archaeological features. Block excavations followed between 2011-2013, revealing a dense, stratified, multi-component site with evidence of bison butchering, multiple hearth features, pottery usage, and an extensive lithic assemblage consisting of over 300 modified stone tools and over 32,000 flakes, the majority made from obsidian. In addition, variation in the archaeological 
composition of the site's cultural components suggests intact occupational layers spanning the middle to late Holocene.

Major objectives of the Pioneer field study were: 1) to establish the geochronology of stratigraphic components at the site, providing ages for preserved archaeological materials; 2) to understand site-formation processes affecting the contexts of archaeological materials; and 3) to better understand the chronology of the Big Lost River's terrace system and its implications for the region's archaeological record. By fulfilling these objectives, we have been able to provide a much-needed open-air geomorphic context for the eastern Snake River Plain's archaeological record over the past $7000+$ years.

\section{METHODS}

Sediments at Pioneer were initially mapped and characterized using standard field-based stratigraphic description and texturing (Hassan, 1978) of all exposed stratigraphic profiles during the 2011-2013 excavation. The sediments were excavated in 5-cm levels within stratigraphic units. Sediment samples were collected from the east wall of the 2011 trench every $5 \mathrm{~cm}$ from the surface down to the base riverbed gravels (Figure 2). Using portions of these samples, standard hydrometer-based particle-size analysis was performed to complement field descriptions (Bouyoucos, 1962). Due to the low organic content of aridisols, soil horizons were identified and characterized according to soil structure and $\mathrm{CaCO}_{3}$ content (based on degree of $\mathrm{HCl}$ effervescence). The cultural sequence was divided into components based on associations with identified paleosols and stratigraphic positions of preserved hearth features and bone/lithic scatters. 
Ages for strata were established through AMS dating of hearth-associated charcoal and burned bone (samples of large in-situ faunal remains associated with occupation surfaces), as well as traces of uncharred organic matter from culturally sterile middle Holocene strata.

Radiocarbon samples were processed by the Arizona Mass Spectrometry Laboratory using standard basic pretreatment procedures consisting of soaking in alternating hydrochloric acid, distilled water, and diluted sodium hydroxide (Donahue, Jull \& Toolin, 1990). Bone was then treated using a modified version of Longin's technique (1971) in which acid was used to remove the apatite fraction, after which the remaining bone collagen was hydrolyzed. Calibrated ages were calculated using Calib software (Stuiver \& Reimer, 1993) and the IntCal13 calibration curve (Reimer et al., 2013).

\section{RESULTS}

Site Geomorphology

The Pioneer site is adjacent to the Big Lost River, which forms a meandering channel at this portion of its course (Figure 1). The river is currently dry most of the year due to modern irrigation practices upstream. The river forms a narrow, meandering valley about 300 meters wide at this bend in the river, though this width varies, and the width of the active floodplain is only about $50 \mathrm{~m}$ wide. The valley is constrained by basaltic lava-flow formations to the north and south that are approximately $7 \mathrm{~m}$ above the channel bottom.

The 2011-2013 Pioneer excavation was situated on a flat alluvial terrace identified as the H1-2 Holocene terrace by Ostenaa and O’Connell (2005) (Figure 3). The surface of this terrace is approximately $2.5 \mathrm{~m}$ above the base of the current river channel, though it should be noted that the depth of the channel has recently been altered somewhat by channel-stabilization via backhoe 
excavation of the current river bed. The excavation block intersects the cutbank, then extends from the channel to the south (magnetic) at a $45^{\circ}$ angle (Figure 3 ).

Adjacent to the H1-2 terrace, on the other side of the Big Lost River, is another higher terrace, approximately 3.5-4 meters above the current river channel, that is composed of unconsolidated sands, gravels, and cobbles and which was identified by Ostenaa and O'Connell (2005) as the P2 terrace (Figure 4). Lower, minimally formed terraces about 1-1.5 $\mathrm{m}$ above the current channel exist approximately 50 meters east of the Pioneer excavation and is identified as terrace H3-4 by Ostenaa and O’Connell (2005) (Figure 4).

\section{Soils and Stratigraphy}

The Pioneer archaeological site's stratigraphic profile can be generally characterized as a set of fine-grained deposits (fine loamy sand and even finer sediments with two horizons containing coarse sand and/or cobbles (Figures 2 and 5). With the exception of a few vertical sagebrush tap-roots, one of which extended to the base of the 2011 excavation, root activity was not an obvious source of bioturbation under $\sim 40 \mathrm{~cm}$ below the surface. Occasional rodent burrows were identified based on pockets of loose or discolored sediment. Stratigraphic layers were discerned, and five different episodes of soil formation were documented based on carbonate accumulation, sub-angular to angular-blocky ped development, and surface stability as indicated by distinct cultural features with charcoal, FCR, lithics, and bone scatters. Stratigraphic units and associated paleosols are described below. Specific sediment characterizations are provided in Table 2.

From the base of the profile, stratum 1 is a layer of loose, structureless, coarse sand and poorly sorted gravels and pebbles. Probes into this layer showed it to be $\sim 30 \mathrm{~cm}$ thick and 
underlain by basalt bedrock. The irregular and undulating shape of this bedrock as seen in various parts of the riverbed suggest the depth of bedrock may be highly variable.

This is followed by stratum 2, a layer of loam that represents the earliest known period of fine-grained alluvial deposition at Pioneer. This layer shows signs of laminar organic staining, and, where exposed, its upper boundary appears to be almost completely horizontal. Because excavations to this depth were limited, however, it is unclear how this boundary appears further from the cut bank. There is no substantive soil structure or effervescence for this stratum.

Stratum 3, originally thought to be a single layer of sandy loam, was sub-divided into six sub-strata of alternating layers of sandy loam, fine sand, loam, and sandy clay loam. These are horizontally bedded with a slight slope toward the cut bank $\left(<10^{\circ}\right)$ and have alternating strong and moderate soil structure, indicating multiple episodes of deposition and soil formation. Extensive $\mathrm{CaCO}_{3}$ concretions and an angular-blocky structure in lower stratum $3 \mathrm{~A}$ indicates this layer potentially represents a soil-formation episode, though the limited exposure of this stratum and the unclear association with overlying $3 \mathrm{C}-3 \mathrm{~F}$ sub-strata due to limited excavation depth make this tentative (Figure 5). Stratum 3B consists of a very thin, 30-cm-long lens of loam with a slightly higher clay content than the surrounding stratum $3 \mathrm{~A}$ stratum and is associated with the neighboring stratum 4 channel feature to the north (Figure 2). Strata 2 and 3 are included in Paleosol 1, which likely represents a series of at least two periods of stability and soil formation/calcium carbonate concretion with stable surfaces at the top of stratum 3D and at or above the top of stratum 3F. However, the full extent of stratum 3's sub-strata and soil-formation episodes are missing due to an unconformity between stratum 3 and the overlying stratum 4 and its sub-strata. Strata 1 and 2 are structureless, representing $\mathrm{C}$ horizons for this soil-formation episode. 
Stratum 4 is generally characterized as a $20-40$-cm-thick layer of large, rounded river cobbles (Figure 6). The northern-most meter of the east profile (Figure 2) shows a trench or channel containing multiple alternating cobble and sandy loam deposits (sub-strata 4A-4F), though stratum 4D extends across the entire block. It lacks smaller pebbles, gravels, or coarse sand, and instead consists almost entirely of a matrix of carbonate-concreted sandy loam and large rounded pebbles and cobbles (generally between $5-10 \mathrm{~cm}$ in diameter) with no evidence of a fining-upward sequence. The base of stratum 4 has a slope of about $30^{\circ}$ at the cut bank, gradually leveling, indicating an unconformity between stratum 4 and the underlying strata.

Stratum 4 is partially overlain by stratum 5 , a thin, somewhat concreted deposit of sandy loam with a similar consistency as the stratum 4 matrix. This stratum is generally thinner to the south of the channel, though it is intermittent in places and its thickness varies. Stratum 5 also has a strong soil structure and effervescence. Paleosol 2 formed during a period of stability at the surface of stratum 5 , forming a $\mathrm{Bk}$ horizon and significantly concreting both stratum 5 and the underlying stratum 4 matrix. Stratum 6 was identified elsewhere at the site but was not exposed at this location.

Stratum 7 is a sandy loam bordering on a loamy sand with weak soil structure and moderate effervescence. While in places it is nearly $50 \mathrm{~cm}$ thick, it thins further from the cut bank, disappearing completely after $\sim 3 \mathrm{~m}$. The upper boundary is somewhat wavy and gently slopes $\left(\sim 10^{\circ}\right)$ toward the cut bank to the north.

Stratum 8 is a sandy loam with strong soil structure and effervescence in addition to an increased quantity of carbonate root or cicada-burrow casts. Like stratum 7, stratum 8 slopes toward the river channel, though at less of an angle $\left(\sim 5^{\circ}\right)$ and with a straighter upper boundary marked by a significant concentration of cultural material. While it becomes thinner at the 
southern end of the block, it does not disappear completely. Paleosol 3 formed from the surface of stratum 8 and formed a Bk horizon that included both strata 7 and 8 , though soil formation is weaker in stratum 7.

Stratum 9 is a sandy loam that was deposited on top of the stable stratum 8 surface. It has moderate soil structure and effervescence and has a smooth, slightly sloping $\left(\sim 5^{\circ}\right)$ upper boundary. It is consistently $\sim 20 \mathrm{~cm}$ thick and extends across the excavation block at Pioneer.

Stratum 10 is a sandy loam overlying stratum 9. It is very similar in consistency and color to stratum 9 , with the primary difference being the weaker structure and decreased calcium carbonate concretion of stratum 10 . The surface of stratum 10 slopes very gradually $\left(\sim 2^{\circ}\right)$ toward the cut bank where it is $20-30 \mathrm{~cm}$ thick. This layer, however, becomes thinner up-slope, disappearing $\sim 5 \mathrm{~m}$ to the south. Strata 9 and 10 are part of Paleosol 4 and likely deposited as part of the same depositional episode, but are separated based on differences in soil structure. The weaker structure of stratum 10 indicates it to be a weak B or even buried A horizon overlying the more concreted (though still only moderately developed) stratum 9 Bk horizon. Strata 11, 12, and 14 were identified elsewhere at the site, but were not exposed at this location.

Stratum 13 is a thin $(5-10 \mathrm{~cm})$ silty loam layer overlying strata 9 and 10. It is nearly horizontal $\left(<2^{\circ}\right.$ slope $)$ and has a strong soil structure and calcium carbonate concretion. It is overlain by stratum 15 , a weakly developed loam that is generally horizontal and $15-20 \mathrm{~cm}$ thick. Above this is stratum 16, which is a very thin $(5-10 \mathrm{~cm})$ layer of loose sandy loam with no soil development. This layer is topped with stratum 17 , which is a thin $(5-10 \mathrm{~cm})$ layer consisting primarily of sagebrush and grass roots and debris. Strata 13-17 comprise the modern soil horizon with an O horizon (stratum 17), a thin A horizon (stratum 16), a second A or weak B horizon (stratum 15), and a more developed but thin Bk horizon (stratum 13). 
Radiocarbon Dating

AMS samples were collected from the 2011 excavation, and thus correlate with the stratigraphic profile in Figure 2. Radiocarbon ages are mostly in stratigraphic order, ranging from $\sim 7300$ to $\sim 670$ cal yr BP (Table 3). Stratum 2 has an associated date of $6,451 \pm 45{ }^{14} \mathrm{C} \mathrm{BP}$ (7278-7431 cal yr BP) (AA97612) run on non-cultural, uncharred organic matter. For the overlying stratum, a total of eight samples were dated, including six on bone and two on charcoal. Of these, four dates from within stratum 4D (AA97614, AA97622, AA97623, and

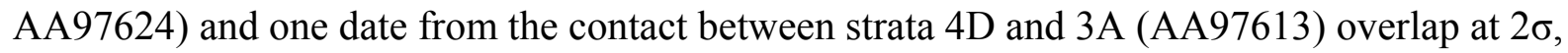
providing a pooled mean of $3539 \pm 19{ }^{14} \mathrm{C}$ BP (3725-3889 cal yr BP). Another date on bone from stratum 4D provides an age of $3,778 \pm 53{ }^{14} \mathrm{C}$ BP (3981-4396 cal yr BP) (AA97615), while an age on charcoal from the contact between strata $4 \mathrm{D}$ and 5 provides an age of $3,060 \pm 120{ }^{14} \mathrm{C} \mathrm{BP}$ (2928-3557 cal yr BP) (AA97616). The final date from stratum 4D is anomalously young, dating to $315 \pm 85{ }^{14} \mathrm{C}$ BP (0-521 cal yr BP) (AA97618). Strata 7-17 are not as well dated, though two dates, including one charcoal date and one bone date, suggest the base of stratum 7 formed $836 \pm$ $25{ }^{14} \mathrm{C}$ BP (694-787 cal yr BP) (AA97620), and stratum 10 formed $716 \pm 25{ }^{14} \mathrm{C} \mathrm{BP}(572-691 \mathrm{cal}$ yr BP) (AA97617).

\section{Cultural Stratigraphy}

Excavations at Pioneer recovered dense concentrations of lithic artifacts and animal bones, numerous hearth features, diagnostic bifacial projectile points, ceramic sherds, and surficial historic debris. Lithic artifacts are overwhelmingly made from obsidian, most likely due to its nearby availability from Big Southern Butte to the south, though some artifacts $(<10 \%)$ are 
made from cryptocrystalline silicates (ccs) or fine-grained volcanics, both of which are present in the river bed. The following briefly describes the cultural materials from the site by stratigraphic layer.

Strata 2 and 3 contain minimal cultural materials including scattered obsidian debitage and a single modified flake. Though a slight increase in flake density occurs near the stratum $2 / 3$ contact, artifacts are still so few as to indicate that they may be displaced via krotovina and other disturbances. This does not preclude, however, that middle Holocene cultural materials may be present elsewhere at the site, as very little of these lower strata was tested.

Stratum $4 \mathrm{C}$ contains the deepest clear cultural component at Pioneer. It consists of numerous obsidian and chert bifaces, modified flakes, and debitage as well as faunal remains and scattered fire-cracked rock (FCR) situated at the contact between strata 4C and 5 and presumably dates to $\sim 3700$ cal yr BP. Two of these bifaces resemble "Beaverhead" variety dart-point preforms described by Swanson (1972) and are likely un-notched Elko or Northern Side-Notched points (Figure 7: a-b). Artifact and bone quantities drop to practically zero at depths greater than $\sim 5 \mathrm{~cm}$ below the top of stratum $4 \mathrm{C}$, though occasional bone fragments occurred within and at the base of stratum $4 \mathrm{C}$.

The top of stratum 5, dating to between $\sim 3700-750$ cal yr BP, yielded a single concentration of FCR associated with expedient tools and multi-directional cores, as well as a bifacial knife/preform, suggesting a possible hearth feature and processing area.

Stratum 7 contains a denser concentration of artifacts than do deeper strata, with a cultural component consisting of over 5000 pieces of debitage associated with charcoal indicating an age of $\sim 750 \mathrm{cal}$ yr BP. This stratum contains a single Desert Side-Notched point 
(Figure 7d) and a re-worked stemmed-point base that resembles an unfinished Haskett point (Figure 7c).

Stratum 8 has the largest and densest concentrations of cultural material in the site, situated primarily near the contact of strata 8 and 9 and contained over 12,000 pieces of debitage. Its age is $\sim 750-630$ cal yr BP. Our excavations yielded six concentrations of FCR, including one rock-oven feature, as well as six dense concentrations of lithic material and bone, and a single Elko style dart point (Figure 7e). Other artifacts include multiple bifaces, cores, modified flakes, one ground-stone fragment, and three ceramic sherds resembling Shoshoni brown-ware.

Strata 9-10, unlike the lower horizons, have no single obvious occupation surface, making it difficult to differentiate between the two during excavation. There are no distinct hearth features, though a diffuse spread of FCR and charcoal around the center of the block is present, dated to $\sim 630$ cal yr BP. Cultural materials include faunal remains, bifacial tools, western-Shoshoni-style ceramic sherds, and debitage. In addition, two Desert Side-Notched points (including one Sierra/Tri-Notched variety), one Avonlea point, three Rosegate points, and four Cottonwood triangular points were found (Figure 7f-o).

Strata 13-17 consist of a low-density concentration of scattered prehistoric/protohistoric and historic debris at or within $30 \mathrm{~cm}$ of the surface and post-dates $\sim 630 \mathrm{cal} \mathrm{yr} \mathrm{BP.} \mathrm{Historic}$ artifacts such as bullet shells, glass, and metal cans were found in association with lithic debitage, bifaces, Shoshoni brown-ware ceramic sherds, and surface hearth features both in the excavation block as well as across the surrounding terrace surface. Point styles associated with these strata include one Desert Side-Notched point, three Rosegate points, five Cottonwood triangular points, and a single small Elko point or large Rosegate point (Figure 7p-t). 


\section{DISCUSSION}

The following discussion is organized into three sections. The first provides a chronology of geomorphological deposition, erosion, and soil-formation episodes at Pioneer in the context of human occupation of the site. Data from Pioneer, combined with existing data provided by Ostenaa and O'Connell (2005), are then used to interpret the sequence of Holocene terrace formation along the Big Lost River valley between the constricted box canyon upstream to the northwest and the playas downstream to the north. Third, possible explanations for the formation of the rounded cobble deposit of stratum 4 and its potential association with a middle-Holocene flood event are discussed.

Site Formation Processes and Cultural Chronology at Pioneer

With the possible exception of strata 15-16 which may be eolian in origin, the sediments from the 2011-2013 excavation at Pioneer consist of alluvial deposits from the adjacent Big Lost River. The earliest period of fine-grained alluvial deposition and soil formation (Stratum 2) began in the early-middle Holocene prior to $\sim 7300$ cal yr BP, and occurred on top of an older, as yet undated lateral channel deposit of coarse sands and gravels. Lower stratum 2 shows signs of horizontal, laminar organic staining, suggesting the area may have had extended periods with shallow standing water. The lack of carbonate concretion in this stratum suggests a period of deposition too rapid or too wet to allow aridisol formation.

Extensive $\mathrm{CaCO}_{3}$ formation took place in Stratum 3A, indicating a period of stability beginning no earlier than $\sim 6600$ cal yr BP, though the cut-and-fill event that formed on top of stratum 4 truncated the upper portions of this horizon. Following this period of stability and lasting until no later than $\sim 3800$ cal yr BP, layers 3C-3F were deposited by overbank flooding. 
Additional layers above these also may have existed, but these were truncated by the unconformity between strata $3 \mathrm{~A}-3 \mathrm{~F}$ and $4 \mathrm{D}$. Strata $3 \mathrm{C}-3 \mathrm{~F}$ have varying degrees of sandiness and alternate between strong and weak aridisol formation, indicating sporadic periods of variable stream flow followed by periods of stability (Paleosol 1). The minimal number and small size of flakes found in strata 2-3 suggest minimal downward displacement via bioturbation, and that the layers are likely culturally sterile. However, this does not preclude the possibility that middle Holocene cultural materials may be present in this horizon elsewhere in the site, as the sediments indicate a low-energy depositional environment (with the possible exception of stratum 3E) and early-middle Holocene diagnostic points (i.e. Haskett, Humboldt and Northern Side-Notched points) have been found on the surface in the vicinity of the site by the 2005 ISU field school.

Following the deposition of strata $3 \mathrm{~A}-3 \mathrm{~F}$, much of these layers was eroded away and capped with the large rounded cobbles of stratum 4 (Figure 6). While the presence of large cobbles may suggest a riverbed or lateral-bar deposit, only the northern-most portion of the profile appears to resemble the edge of a channel, with alternating cobble and sandy-loam deposits. The rest of the profile shows that stratum 4 lacks smaller pebbles, gravels, and coarse sand, instead having a matrix of sandy loam that likely filtered down after the cobbles were deposited. This, coupled with an underlying, intact, horizontally bedded loam horizon that was not fully washed away, suggests a very rapid and short-term increase in river flow intense enough to redistribute large cobbles ranging in size from $5-10 \mathrm{~cm}$ in diameter, suggesting a possible flood event on a local or regional scale. Furthermore, though some of the dates from stratum 4D are likely on non-cultural animal bone redeposited during this flood, multiple AMS dates from stratum 4D show a very narrow range of time, with five overlapping radiocarbon dates from both the surface and base of stratum $4 \mathrm{D}$ providing a pooled mean of $3539 \pm 19{ }^{14} \mathrm{C}$ 
BP (3725-3889 cal yr BP), suggesting this layer was deposited over the course of $\sim 150$ years or less, with the possibility of a single rapid episode as the cause.

This $\sim 3800$ cal yr BP event eroded away portions of the underlying strata $3 \mathrm{~A}-3 \mathrm{~F}$, depositing large cobbles in its wake, but without fining-upward alluvial deposits as would be present in a regular riverbed resulting from prolonged deposition. The "channel" shown in the northernmost profile (Figure 2) possibly represents subsequent, or prior, smaller floods that occurred shortly before or after the primary flood. This may represent the "Older Flood" event mentioned in a few sources (Butler, 1978; Ostenaa \& O'Connell, 2005), though never explained in much detail. The date for this occurrence is not well established, but a general age of 3000$4000{ }^{14} \mathrm{C}$ BP by Butler (1978), and 1000-2000 ${ }^{14} \mathrm{C}$ BP by Ostenaa and O'Connell (2005) may roughly coincide with the Stratum 4 event.

Humans occupied the surface of stratum 4 very shortly following this event, depositing a number of bifacial tools, FCR, and faunal remains directly on the surface of the cobbles. It is likely that these materials are in-situ and not redeposited by the flood, as they are almost exclusively isolated to within $5 \mathrm{~cm}$ of the boundary between stratum $4 \mathrm{D}$ and stratum 5 . They do not penetrate very deeply into the cobbles of stratum $4 \mathrm{D}$, and they occur in three discrete horizontal concentrations of flake and bone. In addition to multiple bone samples collected from stratum 4D dated to $\sim 3800$ cal yr BP, a single sample of charcoal collected from this surface dates to $\sim 3200 \mathrm{cal}$ yr BP, suggesting the primary occupation occurred around $3800 \mathrm{cal}$ yr BP and a potential later occupation occurred on the same surface at $\sim 3200$ cal yr BP. The single Beaverhead A Elko/Bitterroot bifacial preform found in this horizon fits with this time range, though the age range for this artifact form is very broad, ranging anywhere from $\sim 8350-1100 \mathrm{cal}$ yr BP (Swanson, 1972; Holmer, 2009) 
There was a subsequent period of fine-grained deposition (stratum 5) following this occupation which placed a thin layer of sandy loam above and between the cobbles in stratum 4 before stabilizing for an extended period and forming Paleosol 2. Based on current dates, it is unknown when and for how long this period of stability occurred, though charcoal from a feature resting at the top of stratum 5 dates to $\sim 750$ cal yr BP, providing an upper limiting date. During this period, humans appear to have occasionally used the site given the isolated scatter of FCR and artifacts. The extremely limited deposition or possible erosion during this period, however, means the time period between $\sim 3200$ and $\sim 750$ cal yr BP is not well represented in the stratigraphic profile.

Strata 7 and 8 likely formed as part of the same period of increased alluvial deposition, as shown by a similar consistency and slight fining-upward nature in the two combined strata, with the only difference being the degree of soil formation within the Paleosols. Paleosols 3 and 4 began forming in rapid succession at or perhaps just prior to $\sim 750 \mathrm{cal}$ yr BP, with perhaps only 100 years of stability between them, based on dates of $\sim 750 \mathrm{cal} \mathrm{yr}$ BP from the surface of stratum $5 /$ base of stratum 7 and $\sim 630$ cal yr BP from within stratum 10. During the period of stability following the deposition of stratum 8 , this surface was intensively occupied, though the presence of numerous artifacts and features throughout strata 7-13 suggests the site was frequently revisited between periods of increased flooding 800-600 cal yr BP. Flooding deposited a thick layer of sandy loam ranging from 0.5-1.0 $\mathrm{m}$ in thickness over a relatively short period of time, and this correlates both stratigraphically and chronologically with the " 400 -year flood" deposits described by Ostenaa and O'Connell (2005). Increased stream flow likely resulted from higher precipitation, likely creating a favorable environment for hunter-gatherers. 
The presence of Avonlea, Cottonwood, Rosegate, and Desert Side-Notched points in strata 6/7 and 10 corroborates the AMS dates from these horizons. The age range of 750-630 cal yr BP corresponds with the terminal age of Avonlea-style arrow points and the earliest known age of Desert Side-Notched and Cottonwood points in the area ( 650 cal yr BP) (Holmer, 2009). This, combined with an age range of 1650-100 cal yr BP for Rosegate points in the area (Holmer, 2009), correlates with AMS age estimates for these horizons, and suggests that users of these different point forms frequented the Pioneer site for over 100 years. The single Elko point found in stratum 8 post-dates the standard terminal age of Elko $(\sim 1150$ cal yr BP) (Holmer, 2009) by roughly 400 years. Likewise, the possible un-ground Haskett fragment post-dates the latest known Haskett and Birch Creek points in the area ( 8350 cal yr BP) (Holmer, 2009) by nearly 8000 years. However, the common presence of these forms on the surface in the immediate vicinity suggests that these points may have been collected and recycled by later occupants.

Following a short period of stability after the formation of Paleosol 4, the modern soil horizon began forming in sediments deposited sometime after $\sim 600 \mathrm{cal}$ yr BP. Though radiocarbon ages were not acquired for these deposits, the mixed historic and prehistoric materials suggest humans continued to occupy the site through the late prehistoric and protohistoric periods. The sediments in this uppermost horizon, though, appear somewhat mixed and loose, resembling a "plow zone," though it was more likely the result of trampling by people or cattle, or the re-deposition of loose sediment as a result of nearby historic excavation activities. Rosegate, Cottonwood, and Desert Side-Notched points are present in this horizon and confirm a late-Archaic age, though again these may be mixed or re-deposited from slightly lower horizons elsewhere at the site. 


\section{Holocene Big Lost River Terrace Formation}

The Big Lost River terraces were classically defined as a series of gravelly bar and meander channels formed as a result of middle/late Pleistocene flooding and glacial melt (Nace, Deutsch \& Voegeli, 1956; Nace et al., 1975; Cerling, Poreda \& Rathburn, 1994; Gianniny et al., 1997; Geslin, Link \& Fanning, 1999; Knudsen et al., 2002). As defined by Ostenaa and O’Connell (2005), Pleistocene deposits near Pioneer can be split into three separate terraces. The P-1 and P-2 terraces (4.0-4.5 $\mathrm{m}$ above channel) formed through high-energy floods and glacial melt and resemble braided-stream deposits of poorly sorted gravels and cobbles topped by eolian mima-mound formations that likely developed sometime in the late Pleistocene. The P-3 terrace formed in the late Pleistocene and is associated with the Big Lost River's shift to a channelized meandering stream, though without any known traces of fine-grained overbank flood deposits.

It was not until recently that Holocene-age terraces were characterized along portions of the Big Lost River by Ostenaa and O’Connell (Ostenaa et al., 1999; Ostenaa \& O'Connell, 2005). Though they are sporadic and only present on a relatively short stretch of the river between Lake Terreton's bed to the north and the box canyon and lava flows to the northwest, these deposits tend to be fine-grained overbank flood deposits. These terraces are sporadic and range in width from a few meters to as much as $100 \mathrm{~m}$ wide in some places (Figure 4).

Based on the work presented here, the earliest Holocene-aged terrace, H1 (2.5-3.0 m above channel), began accumulating just prior to 7300 cal yr BP. Alternating layers of slightly coarser or slightly finer sediments with bands of organic staining indicate variable discharge, with periods of very low energy flow and marshy conditions in the immediate area early on. Deposition continued until sometime between 6600 and $3800 \mathrm{cal}$ yr BP, at which time a high- 
energy alluvial episode occurred. This potentially corresponds to the "older flood" described by Ostenaa and O'Connell (2005), which partially eroded terrace H1 and deposited a layer of large rounded cobbles (stratum 4) likely re-deposited from eroded P1-3 gravel deposits upstream.

Following the accumulation of a thin layer of stratum 5 deposits over stratum 4 , there was a period of stability lasting until $\sim 800 \mathrm{cal}$ yr BP, after which rapid alluvial deposition occurred, forming terrace $\mathrm{H} 2$ (1.8-2.2 $\mathrm{m}$ above channel) by depositing alluvium over the remnants of terrace H1, potentially correlating with the "400-year flood" described by Ostenaa and O'Connell (2005) and the refilling of the playas to the north (Bright \& Davis, 1982; Ostenaa et al., 1999). This deposition occurred over a period of at least 100 years, corresponding with a period of frequent habitation by prehistoric groups, and was probably the result of a period of increased precipitation, potentially correlating with the end of the Medieval Climatic Anomaly (1150-700 cal yr BP) (Stine, 1994; Kleppe et al., 2011). This period may have correlated with the formation of the lower H3-4 terraces (1-1.8 $\mathrm{m}$ above channel) described by Ostenaa and O'Connell (2005), though these terraces were not present at tested portions of Pioneer.

\section{The Pioneer Flood Event}

Ostenaa and O'Connell (2005) date a middle-Holocene Big Lost River flood event, referred to as the "Older Flood," to approximately 2000-1000 cal yr BP, though they recognize the weakness of their radiocarbon chronology in accurately dating this event, indicating that it may have occurred as much as 2000 years earlier, as suggested by Butler (1978). Ostenaa and O'Connell (2005) describe this flood as having been high enough to top the H1-2 terraces, based on the unconformity between these layers and the "400-year flood" deposition (Paleosols 2 and 3). Based on ages from Pioneer, it would appear that this flood is represented by stratum 4 and 
therefore occurred between 3889-3725 cal yr BP. While it was very intense, it occurred over a very short period of time and covered a limited geographic area. Given the clear dating of this flood at the Pioneer site, I propose the name "Pioneer Flood" event to distinguish it from others.

The most likely source for this flood is a sudden increase in stream flow that was amplified by the constricted, $11 \mathrm{~km}$ long Box Canyon portion of the Big Lost River (Figure 1) to create a narrow but very high-energy flow of water downstream to the Pioneer area. The terminus of this canyon is only $4 \mathrm{~km}$ upstream of Pioneer, and the resulting localized flood could have eroded the $\mathrm{H} 1$ terrace and redeposited large round cobbles in its wake over a very short period of time. Due to the constricted nature of the canyon, higher rates of water velocity and transport are possible despite a relatively small increase in water. The late Pleistocene "Big Lost River Flood" that flowed through the same box canyon, as described by Rathburn (1993), despite its relatively small size, had the third-highest documented flood power on record after the Missoula and Bonneville floods.

Due to the scarcity of a solid regional geomorphic record along this stretch of the Big Lost River, it is not clear what may have caused this event. There are no correlated features recorded upstream in the Mackay area, though studies of late Holocene deposits are scarce for this region. The only potential correlate is the Carlson landslide, a moist landslide that originated in the Lost River Range $\sim 80 \mathrm{~km}$ to the north that occurred $\sim 3700$ cal yr BP and contained a large amount of water (Shaller, 1991). While the ultimate cause was a gradual weakening of the substrate, the trigger for this event could potentially have been caused by intense precipitation. One possibility is that its timing corresponds to the onset of increased precipitation of the late Holocene, estimated to have occurred between $~ 3500-2800$ cal yr BP based on ages from Gray's 
Lake (Beiswenger, 1991) and Rattlesnake Cave (Bright \& Davis, 1982). However, this would not necessarily explain such an abrupt event.

Another possible explanation is that the erosion of the $\mathrm{H} 1$ terrace and deposition of the Stratum 4 cobble layer is tied to volcanic activity at Craters of the Moon, located $\sim 25 \mathrm{~km}$ southwest of Pioneer. Craters of the Moon consists of basaltic Pahoehoe lava flows that formed from multiple shield volcanos and fissure eruptions during the Pleistocene and Holocene. The Minidoka eruption, in particular, was the largest of the Eruptive Period B eruptions of the middle-late Holocene and formed a $\sim 250 \mathrm{~km}^{2}$ lava field. This lava field originated from the "Great Rift" fissure system of cinder cones and vents $>40 \mathrm{~km}$ long and up to $10 \mathrm{~km}$ wide (Kuntz et al., 1986; Kuntz, Covington \& Schorr, 1992; Henrikson, 2008). This eruption would have consisted of several days of violent expulsion of gas-charged molten lava and tephra followed by a subsequent massive lava flow dated to 4085-3701 cal yr BP (W-4447) (Kuntz et al., 1986), overlapping at $2 \sigma$ the pooled mean age of the five dates acquired from the stratum 4 cobble layer at Pioneer (3889-3725 cal yr BP). A similar eruption at nearby Devil's Cauldron was similarly dated to 4149-3839 cal yr BP (W-4339), also potentially overlapping the pooled mean age from Pioneer stratum 4.

This period of increased volcanism generated intense ashfall, heat, and even brushfires from the associated initial blasts and cinder cone formations; potentially enough to create local super-storms in the nearby Lost River Range and Pioneer Mountains and a sudden increase in precipitation that could have affected Pioneer and potentially even the Carlson landslide. A similar effect has been documented by Bell and House (2007) as occurring at over 20 sites in western Nevada where large, cobble-filled flash-flood deposits were found to consistently overlay intact fine-grained alluvial deposits and tephra from eruptions at Mono and Inyo crater 
beds during the late Holocene. An increase in river flow could also have originated from rapid snowmelt due to tephra-fall-induced decreased albedo of nearby snowpack and glaciers in the mountains downwind directly to the north and northeast (e.g. Nield et al., 2013). While the degree of tephra ejection was substantially less than the classic Plinian eruptions of the Mono and Inyo craters, the initial eruption could have been enough to trigger flash flooding on a local scale. The now mostly destroyed Minidoka vent complex lies $\sim 35 \mathrm{~km}$ southwest of the Big Lost River, and the Devil's Cauldron cinder cone and subsequent flow is $\sim 25 \mathrm{~km}$ to the southwest

(Figure 1), and lie less than $50 \mathrm{~km}$ south of the mountains to the north. However, intensive studies of Holocene-aged alluvial deposits along this portion of the Big Lost River are needed to further corroborate this proposed flood event.

\section{CONCLUSIONS}

Like many rivers in the Intermountain West, the Big Lost River during the Holocene was previously characterized as a very low energy, seasonally flowing stream running through remnant Pleistocene-aged channels toward the Big Lost River Sinks on the current day Idaho National Laboratory, assuming little to no significant deposition during the Holocene. However, recent work by Ostenaa and O'Connell (2005) as well as this study show a much more complex and dynamic history. Besides evidence for multiple episodes of terrace formation and erosion during the Pleistocene and through much of the Holocene, there is evidence for flash floods during the middle-late Holocene triggered by either climate change or volcanic eruptions. Otherwise, the thick deposits of fine-grained overbank flood alluvium provide a valuable opportunity for future studies to find and excavate preserved, stratified sub-surface human occupations dating to the Holocene and possibly even terminal Pleistocene in an arid 
environment otherwise dominated by surface palimpsest sites. The Pioneer excavation confirms this assessment, providing evidence of multiple cultural occupations spanning more than 3700 years, making it one of a handful of open-air, stratified multi-component sites to be excavated in the Intermountain desert West.

In addition to providing a cultural record, the sedimentary record at Pioneer provides insight into the paleoclimatic history of southeastern Idaho and the greater Intermountain West from the early-middle Holocene transition $\sim 7200$ cal yr BP to the historic period. Based on dated cycles of deposition and stability at Pioneer as a proxy, the middle Holocene in this region appears to have fluctuated between wet and dry periods, with at least three cycles between 72003800 cal yr BP, potentially corroborating the concept of a fluctuating climate during the middle Holocene on the Snake River Plain, as suggested by Wigand (1997) and Beiswenger (1991). Conversely, there is a lack of deposition during much of the late Holocene when climatic conditions are generally thought have to become wetter (Bright, 1966; Bright \& Davis, 1982; Beiswenger, 1991). More recent paleosols at Pioneer indicate a period of cooler and wetter climate in the region between 750-630 cal yr BP, potentially correlating with the early onset of the Little Ice Age.

Though they provide a coarse proxy record of paleoclimate, much of the existing lakecore pollen records (Bright, 1966; Bright \& Davis, 1982; Davis, Sheppard \& Robertson, 1986; Beiswenger, 1991) for the region are becoming increasingly outmoded, necessitating the need for new high-resolution proxy records. Moreover, future geoarchaeological testing is required along the Big Lost River, to fully assess the archaeological and paleoclimatic potential of these Holocene-aged terraces as well as to further clarify the potential link between the "older flood" event and volcanic activity during the mid-late Holocene. Such methods of geomorphological 
alluvial terrace testing need to be more extensively applied in arid environments across the Intermountain West to identify intact, open-air subsurface sites and better understand Holocene climate fluctuation.

\section{ACKNOWLEDGEMENTS}

This research was initiated and funded by the Idaho National Laboratory CRM department under supervision from the United States Department of Energy Idaho Operations Office (contract \# DE-AC07-05ID14517). I would specifically like to thank the tireless efforts of INL archaeologists Clayton Marler, Hollie Gilbert, Brenda Pace, Julie Braun-Williams, and Christina Olsen, who initiated the Pioneer project and got me involved in Idaho archaeology, as well as the efforts of the rest of the CRM staff who made this possible, and the Department of Energy staff for overseeing my excavation permit. I would also like to thank the Shoshone-Bannock tribes of the Fort Hall Reservation for their support and excavation assistance, as well as the efforts of Kelly Graf, Marti Brooks, Jessi Halligan, Adam Burke, Cameron Brizzee, and the Texas A\&M 2012 field school for their help with field work. I also owe a great gratitude to the Center for the Study of the First Americans at Texas A\&M for their support and lab space, and would especially like to thank my graduate committee chair Dr. Ted Goebel, who helped every step of the way, and committee members Drs. Michael Waters, David Madsen, and Vatche Tchakerian as well as the anonymous reviewers and editors of Geoarchaeology who helped me improve the quality of this manuscript. I would also like to thank the University of Arizona Accelerator Mass Spectrometry Laboratory for processing AMS dates. Finally, I would to thank my wife Marion and my parents John and Teresa for their useful advice and for putting up with my nonsense. 


\section{REFERENCES}

Aikens, C.M. (1970). Hogup Cave. University of Utah Anthropological Papers, No. 93. Salt Lake City: University of Utah Press.

Aikens, C.M., \& Greenspan, R.L. (1988). Ancient lakeside culture in the northern Great Basin: Malheur Lake, Oregon. Journal of California and Great Basin Anthropology, 10(1), 32-61.

Beck, C., \& Jones, G.T. (2009). The archaeology of the eastern Nevada Paleoarchaic. Part 1: The Sunshine Locality. Salt Lake City: University of Utah Press.

Beck, C., \& Jones, G.T. (1997). The terminal Pleistocene/early Holocene archaeology of the Great Basin. Journal of World Prehistory, 11(2), 161-236.

Beiswenger, J.M. (1991). Late Quaternary vegetational history of Grays Lake, Idaho. Ecological Monographs, 6(2), 165-182.

Bell, J.W., \& House, P.K. (2007). Did Plinian eruptions in California lead to debris flows in Nevada? An intriguing stratigraphic connection. Geology, 35(3), 219-222.

Bonstead, L.M. (2000). The Nials Site: An early Holocene occupation in the Harney Basin, Oregon. Unpublished M.A. thesis, University of Nevada, Reno.

Bouyoucos, G.J. (1962). Hydrometer method improved for making particle size analyses of soils. Agronomy Journal, 54(5), 464-465.

Bright, R.C. (1966). Pollen and seed stratigraphy of Swan Lake, southeastern Idaho: Its relation to regional vegetational history and to Lake Bonneville history. Tebiwa, 9(2), 1-47.

Bright, R.C., \& Davis, O.K. (1982). Quaternary paleoecology of the Idaho National Engineering Laboratory, Snake River Plain, Idaho. American Midland Naturalist, 108(1), 21-33.

Butler, B.R. (1972). The Holocene or postglacial ecological crisis on the eastern Snake River Plain. Tebiwa, 15(1), 49-61.

Butler, B.R. (1968). An introduction to archaeological investigations in the Pioneer Basin Locality of eastern Idaho. Tebiwa, 11(1), 1-30.

Butler, B.R. (1978). A Guide to understanding Idaho archaeology: the upper Snake and Salmon River country. Pocatello: A Special Publication of the Idaho Museum of Natural History.

Cerling, T.E., Poreda, R.J., \& Rathburn, S.L. (1994). Cosmogenic 3He and $21 \mathrm{Ne}$ age of the Big Lost River flood, Snake River Plain, Idaho. Geology, 22(3), 227-230.

Connolly, T.J. (1999). Newberry Crater: a ten-thousand-year record of human occupation and environmental change in the basin-plateau borderlands. University of Utah Anthropological 
Papers, No. 121. Salt Lake City: Museum of Natural History and Department of Anthropology, University of Oregon.

Davis, J.O., \& Rusco, M.K. (1987). The Old Humboldt site - 26PE670. In M.K. Rusco \& J.O. Davis (Eds.), Studies in Archaeology, Geology and Paleontology at Rye Patch Reservoir, Pershing County, Nevada (pp.41-69). Nevada State Museum Anthropological Papers, No. 20. Carson City.

Davis, L.C. (2005). Geoarchaeological lessons from an alluvial fan in he lower Salmon River Canyon, Idaho. Idaho Archaeologist, 28(1), 3-12.

Davis, L.G., \& Schweger, C.E. (2004). Geoarchaeological context of late Pleistocene and early Holocene occupation at the Cooper's Ferry Site, western Idaho, USA. Geoarchaeology: An International Journal, 19(7), 685-704.

Davis, O.K., Sheppard, J.C., \& Robertson, S. (1986). Contrasting climatic histories for the Snake River Plain, Idaho, resulting from multiple thermal maxima. Quaternary Research, 26(3), 321339.

Donahue, D.J., Jull, A.J.T., \& Toolin, L.J. (1990). Radiocarbon Measurements at the University Of Arizona AMS Facility. Nuclear Instruments \& Methods in Physics Research Section B, 52(34), 224-228.

Dugas, D.P., Elston, R.G., Carter, J.A., Ataman, K., \& Bullock, M. (1995). An archaeological and stratigraphic assessment of the Stubblefield Lookout Tower site (35Ha53), Malheur National Wildlife Refuge. Cultural Resource Series, No. 11. Portland: U.S. Department of the Interior Fish and Wildlife Service Region 1.

Galm, J.R., \& Gough, S. (2001). Site 45KT1362, a c. 10,000 yr BP occupation in central Washington. Current Research in the Pleistocene, 17, 29-31.

Geslin, J.K., Link, P.K., \& Fanning, C.M. (1999). High-precision provenance determination using detrital-zircon ages and petrography of Quaternary sands on the eastern Snake River Plain, Idaho. Geology, 27(4), 295-298.

Gianniny, G.L., Geslin, J.K., Riesterer, J.W., Link, P.K., \& Thackray, G.D. (1997). Quaternary surficial sediments near Test Area North (TAN), northeastern Snake River Plain; an actualistic guide to aquifer characterization. In S. Sharma \& J.H. Hardcastle (Eds.), Proceedings, 32nd Annual Symposium on Engineering Geology and Geotechnical Engineering (pp.29-44). Moscow: University of Idaho.

Gilbert, H.K., Braun, J.B., Heath, G., Pace, B.R., \& Scott, C. (2009). Geophysical investigations of the archaeological resources at the Powell Stage Station, Proceedings of the Symposium on the Application of Geophysics to Engineering and Environmental Problems (1051-1060), Fort Worth. 
Goebel, T., Waters, M.R., \& Dikova, M. (2003). The archaeology of Ushki Lake, Kamchatka, and the Pleistocene peopling of the Americas. Science, 301(5632), 501-505.

Graf, K.E. (2007). Stratigraphy and chronology of the Pleistocene to Holocene transition at Bonneville Estates Rockshelter, eastern Great Basin. In K.E. Graf \& D.N. Schmitt (Eds.), Paleoindian or Paleoarchaic? Great Basin human ecology at the Pleistocene/Holocene transition (pp.82-104). Salt Lake City: University of Utah Press.

Green, J.P. (1972). Archaeology of the Rock Creek Site 1O-CA-33, Sawtooth National Forest, Cassia County, Idaho. Unpublished M.A. thesis, Idaho State University, Pocatello.

Green, T.J., Cochran, B., Fenton, T.W., Woods, J.C., Titmus, G.L., Tieszen, L., Davis, M.A., \& Miller, S.J. (1998). The Buhl burial: A Paleoindian woman from southern Idaho. American Antiquity, 63(3), 437-456.

Gruhn, R. (2006). New excavations at Wilson Butte Cave, south-central Idaho. Occasional Papers of the Idaho Museum of Natural History, No. 38. Pocatello: Idaho State University.

Gruhn, R. (1961). A collection of artifacts from Pence-Duerig Cave in south-central Idaho. Tebiwa, 4(1), 1-24.

Hassan, F.A. (1978). Sediments in archaeology: methods and implications for palaeoenvironmental and cultural analysis. Journal of Field Archaeology, 5(2), 197-213.

Helzer, M.M. (2004). Archaeological investigations at the Bergen site: middle Holocene lakeside occupations near Fort Rock, Oregon. In D.L. Jenkins, T.J. Connolly \& C.M. Aikens (Eds.), Early and Middle Holocene Archaeology of the northern Great Basin (pp.77-93). University of Oregon Anthropological Papers, No. 62. Eugene: Museum of Natural History and Department of Anthropology, University of Oregon.

Henrikson, L.S. (2003). Bison freezers and hunter-gatherer mobility: Archaeological analysis of cold lava tube caves on Idaho's Snake River plain. The Plains Anthropologist, 48(187), 263-285.

Henrikson, L.S. (2008). Going with the flow: The impact of Holocene fissure eruptions on obsidian source use in southeastern Idaho. Journal of California and Great Basin Anthropology, 28(2), 153-165.

Hicks, B.A. (2004). Marmes Rockshelter :A final report on 11,000 years of cultural use. Pullman: Washington State University Press.

Holmer, R.N. (2009). Field guide: Projectile points of eastern Idaho. Pocatello: Idaho Museum of Natural History, Idaho State University.

Holmer, R.N., \& Ringe, B.L. (1986). Excavations at Wahmuza. In R.N. Holmer (Ed.), ShoshoneBannock culture history (pp.39-203). Swanson-Crabtree Anthropological Research Laboratory Reports of Investigations, No. 85.16. Pocatello: Idaho State University. 
Huckleberry, G. (2001). Archaeological sediments in dryland alluvial environments. In J.K. Stein \& W.R. Farrand (Eds.), Sediments in archaeological context (pp.67-92). Salt Lake City: University of Utah Press.

Hull, K.L. (2001). Reasserting the utility of obsidian hydration dating: A temperature-dependent empirical approach to practical temporal resolution with archaeological obsidians. Journal of Archaeological Science, 28(10), 1025-1040.

Irwin, A.M., \& Moody, U.L. (1978). The Lind Coulee Site (45GR97). Washington Archaeological Research Center Project Report, No. 56. Pullman: Washington State University.

Jenkins, D.L., Droz, M.S., \& Connolly, T.J. (2004). Geoarchaeology of wetland settings in the Fort Rock Basin, south-central Oregon. In D.L. Jenkins, T.J. Connolly \& C.M. Aikens (Eds.), Early and Middle Holocene Archaeology of the Northern Great Basin (pp.31-52). University of Oregon Anthropological Papers, No. 62. Eugene: University of Oregon Museum of Natural History and Department of Anthropology.

Jenkins, D.L. (2004). The grasshopper and the ant: Middle Holocene occupations and storage behavior at the bowling dune site in the Fort Rock Basin, central Oregon. In D.L. Jenkins, T.J. Connolly \& C.M. Aikens (Eds.), Early and middle Holocene archaeology of the northern Great Basin (pp.123-155). University of Oregon Anthropological Papers, No. 62. Eugene: Museum of Natural History and Department of Anthropology, University of Oregon.

Jenkins, D.L. (1994). Archaeological investigations at three wetland sites in the Silver Lake area of the Fort Rock basin. In C.M. Aikens \& D.L. Jenkins (Eds.), Archaeological researches in the northern Great Basin: Fort Rock Archaeology since Cressman (pp.213-258). University of Oregon Anthropological Papers, No. 50. Eugene: Museum of Natural History and Department of Anthropology, University of Oregon.

Jenkins, D.L., Davis, L.G., Stafford, T.W., Campos, P.F., Hockett, B., Jones, G.T., Cummings, L.S., Yost, C., Connolly, T.J., Yohe, R.M., Gibbons, S.C., Raghavan, M., Rasmussen, M., Paijmans, J., Hofreiter, M., Kemp, B.M., Barta, J.L., Monroe, C., Gilbert, M., \& Willerslev, E. (2012). Clovis age Western Stemmed projectile points and human coprolites at the Paisley Caves. Science, 337(6091), 223-228.

Jennings, J.D. (1957). Danger Cave. University of Utah Press Anthropological Papers, No. 27. Salt Lake City: University of Utah.

Kelly, R.L. (1999). Theoretical and archaeological insights into foraging strategies among the prehistoric inhabitants of the Stillwater Marsh wetlands. In B.E. Hemphill \& C.S. Larsen (Eds.), Prehistoric Lifeways in the Great Basin Wetlands: Bioarchaeological Reconstruction and Interpretation (pp.117-150). Salt Lake City: University of Utah Press.

Kleppe, J.A., Brothers, D.S., Kent, G.M., Biondi, F., Jensen, S., \& Driscoll, N.W. (2011). Duration and severity of Medieval drought in the Lake Tahoe Basin. Quaternary Science Reviews, 30(23), 3269-3279. 
Knudsen, K.L., Sowers, J.M., Ostenaa, D.A., \& Levish, D.R. (2002). Evaluation of glacial outburst flood hypothesis for the Big Lost River, Idaho. In P.K. House, R.H. Webb, V.R. Baker \& D.R. Levish (Eds.), Ancient floods, modern hazards (pp.217-235). Water Science and Application, No. 5. Washington D.C.: American Geophysical Union.

Kuntz, M.A., Covington, H.R., \& Schorr, L.J. (1992). An overview of basaltic volcanism of the eastern Snake River Plain, Idaho. In P.K. Link, M.A. Kuntz \& L.B. Platt (Eds.), Regional geology of eastern Idaho and western Wyoming (pp.227-268). Geological Society of America Memoir, No. 179. Boulder.

Kuntz, M.A., Spiker, E.C., Rubin, M., Champion, D.E., \& Lefebvre, R.H. (1986). Radiocarbon studies of latest Pleistocene and Holocene lava flows of the Snake River Plain, Idaho: Data, lessons, interpretations. Quaternary Research, 25(2), 163-176.

Lohse, E.S. (1994). Southeastern Idaho prehistory: Status and stasis. Idaho Archaeologist, 17(2), $35-46$.

Lohse, E.S. (1989). Aviator's Cave. Idaho Archeologist, 12(2), 23-28.

Longin, R. (1971). New method of collagen extraction for radiocarbon dating. Nature, 230(5291), 241-242.

Madsen, D.B. (2005). Buzz-Cut Dune and Fremont foraging at the margin of horticulture. Salt Lake City: University of Utah Press.

Mehringer, P.J., \& Cannon, W.J. (1994). Volcaniclastic dunes of the Fort Rock Valley, Oregon: stratigraphy, chronology, and archaeology. In C.M. Aikens \& D.L. Jenkins (Eds.), Archaeological Researches in the Northern Great Basin: Fort Rock Archaeology Since Cressman (pp.283-327). University of Oregon Anthropological Papers, No. 50. Eugene: Museum of Natural History and Department of Anthropology, University of Oregon.

Miller, S.J. (1982). The archaeology and geology of an extinct megafauna/fluted-point association at Owl Cave, the Wasden site, Idaho: A preliminary report. In J.E. Ericson, R.E. Taylor \& R. Berger (Eds.), Peopling of the New World (pp.81-95). Ballena Press Anthropological Papers, No. 23. Los Altos.

Miller, S.J. (1972). Weston Canyon rockshelter: Big-game hunting in southeastern Idaho. Unpublished M.A. thesis, Idaho State University, Pocatello.

Moessner, J. (2004). DJ Ranch: A mid- to late-Holocene occupation site in the Fort Rock Valley, south-central Oregon. In D.L. Jenkins, T.J. Connolly \& C.M. Aikens (Eds.), Early and Middle Holocene Archaeology of the Northern Great Basin (pp.95-122). University of Oregon Anthropological Papers, No. 62. Eugene: Museum of Natural History and Department of Anthropology, University of Oregon. 
Nace, R.L., Deutsch, M., \& Voegeli, P.T. (1956). Geography, geology, and water resources of the National Reactor Testing Station, Idaho, Part 2: Geography and geology (Rep. No. IDO22033-USGS). Boise: U.S. Department of Interior, Geological Survey, Water Resources Division, Ground Water Branch.

Nace, R.L., Voegeli, P.T., Jones, J.R., \& Deutsch, M. (1975). Generalized geologic framework of the National Reactor Testing Station. U.S. Geological Survey Professional Paper, No. 725-B. Washington D.C.: United States Department of the Interior.

Nield, J.M., Chiverrell, R.C., Darby, S.E., Leyland, J., Vircavs, L.H., \& Jacobs, B. (2013). Complex spatial feedbacks of tephra redistribution, ice melt and surface roughness modulate ablation on tephra covered glaciers. Earth Surface Processes and Landforms, 38(1), 95-102.

O'Connell, J.,F. (1975). The prehistory of Surprise Valley. Bellena Press Anthropological Papers, No. 4. Ramona.

Oetting, A.C. (1994a). Chronology and time markers in the northwestern Great Basin: the Chewaucan basin cultural chronology. In C.M. Aikens \& D.L. Jenkins (Eds.), Archaeological Researches in the Northern Great Basin: Fort Rock Archaeology since Cressman (pp.41-62). University of Oregon Anthropological Papers, No. 50. Eugene: Museum of Natural History and Department of Anthropology, University of Oregon.

Oetting, A.C. (1994b). Early Holocene rabbit drives and prehistoric land use patterns on Buffalo Flat, Christmas Lake Valley, Oregon. In C.M. Aikens \& D.L. Jenkins (Eds.), Archaeological Researches in the northern Great Basin: Fort Rock Archaeology since Cressman (pp.155-169). University of Oregon Anthropological Papers, No. 50. Eugene: Museum of Natural History and Department of Anthropology, University of Oregon.

Oetting, A.C. (1989). Villages and wetlands adaptations in the northern Great Basin: chronology and land use in the Lake Abert-Chewaucan Marsh Basin, Lake County, Oregon. University of Oregon Anthropological Papers, No. 41. Eugene: Museum of Natural History and Department of Anthropology, University of Oregon.

O'Neill, B.L. (2004). Evidence for early Holocene interaction between the upper Umpqua River drainage and the northern Great Basin. In D.L. Jenkins, T.J. Connolly \& C.M. Aikens (Eds.), Early and Middle Holocene Archaeology of the Nothern Great Basin (pp.209-220). University of Oregon Anthropological Papers, No. 62. Eugene: Museum of Natural History and Department of Anthropology, University of Oregon.

Ostenaa, D.A., Levish, D.R., Klinger, R.E., \& O’Connell, D.R. (1999). Phase 2 paleohydrologic and geomorphic studies for the assessment of flood risk for the Idaho National Engineering and Environmental Laboratory, Idaho (Rep. No. 99-7). Denver: Geophysics, Paleohydrology, and Seismotectonics Group. 
Ostenaa, D.A., \& O'Connell, D.R.H. (2005). Big Lost River flood hazard study, Idaho National Laboratory, Idaho. Summary document (Rep. No. 2005-2). Idaho Falls: Idaho National Laboratory.

Pinson, A.O. (2004). Of lakeshores and dry basin floors: A regional perspective on the early Holocene record of environmental change and human adaptation at the Tucker site. In D.L. Jenkins, T.J. Connolly \& C.M. Aikens (Eds.), Early and Middle Holocene Archaeology of the Northern Great Basin (pp.53-76). University of Oregon Anthropological Papers, No. 62. Eugene: Museum of Natural History and Department of Anthropology, University of Oregon.

Plew, M.G., \& Woods, J.C. (1985). Text excavations at the Kueney Site (10-TF-527): A Middle Archaic site in the South Hills Country. Idaho Archaeologist, 8(1), 27-36.

Powers, W.R. (1966). Archaeological Excavations in Willow Creek Canyon, Southeastern Idaho, 1966. Occasional Papers of the Museum, No. 25. Pocatello: Idaho State University.

Rathburn, S.L. (1993). Pleistocene cataclysmic flooding along the Big Lost River, east central Idaho. Geomorphology, 8(4), 305-319.

Raven, C., \& Elston, R.G. (1989). Prehistoric human geography in the Carson Desert, pt. 1: A predictive model of land use in the Stillwater wildlife management area. Cultural Resource Series, No. 3. Portland: US Department of the Interior, US Fish and Wildlife Service, Region 1.

Reimer, P.J., Bard, E., Bayliss, A., Beck, J.W., Blackwell, P.G., Bronk Ramsey, C., Buck, C.E., Cheng, H., Edwards, R.L., Friedrich, M., Grootes, P.M., Guilderson, T.P., Haflidason, H., Hajdas, I., Hatté, C., Heaton, T.J., Hoffmann, D.L., Hogg, A.G., Hughen, K.A., Kaiser, K.F., Kromer, B., Manning, S.W., Niu, M., Reimer, R.W., Richards, D.A., Scott, E.M., Southon, J.R., Staff, R.A., Turney, C.S.M., \& van der Plicht, J. (2013). IntCal13 and Marine13 radiocarbon age calibration curves 0-50,000 years cal BP. Radiocarbon, 55(4), 1869-1887.

Rogers, A.K., \& Duke, D. (2011). An archaeologically validated protocol for computing obsidian hydration rates from laboratory data. Journal of Archaeological Science, 38(6), 13401345.

Rusco, M.K., \& Davis, J.O. (1987). Sand Island (26PE450) and the Sandy Bank Site (26PE366). In M.K. Rusco \& J.O. Davis (Eds.), Studies in Archaeology, Geology and Paleontology at Rye Patch Reservoir, Pershing County, Nevada (pp.74-155). Nevada State Museum Anthropological Papers, No. 20. Carson City: Nevada State Museum.

Rusco, M.K. (1987). Studies in archaeology, geology, and paleontology at Rye Patch Reservoir, Pershing County, Nevada. Anthropological Papers, No. 20. Carson City: Nevada State Museum.

Schneider, J.S. (2002). Analysis of ground stone artifacts. In M.Q. Sutton \& B.S. Arkush (Eds.), Archaeological laboratory methods: an introduction (pp.68-104). Dubuque: Kendall Hunt Publishing Company. 
Shaller, P.J. (1991). Analysis of a large moist landslide, Lost River range, Idaho, USA. Canadian Geotechnical Journal, 28(4), 584-600.

Simms, S.R. (1999). Farmers, foragers, and adaptive diversity: The Great Salt Lake wetlands project. In B.E. Hemphill \& C.S. Larsen (Eds.), Prehistoric lifeways in the Great Basin Wetlands: Biological reconstruction and interpretation (pp.21-54).

Stine, S. (1994). Extreme and persistent drought in California and Patagonia during Mediaeval time. Nature, 369(6481), 546.

Stuiver, M., \& Reimer, P.J. (1993). Extended ${ }^{14} \mathrm{C}$ database and revised CALIB radiocarbon calibration program. Radiocarbon, 35(1), 215-230.

Swanson, E.H.J. (1972). Birch Creek: Human ecology in the cool desert of the northern Rocky Mountains 9,000 B.C.-A.D. 1850. Pocatello: Idaho State University Press.

Swanson, E.H.J., \& Sneed, P.G. (1971). Jackknife Cave. Tebiwa, 14(1), 33-69.

Swanson, E.H.J., \& Dayley, J. (1968). Hunting at Malad Hill in southeastern Idaho. Tebiwa, 11(2), 59-69.

Swanson, E.H.J., Butler, B.R., \& Bonnichsen, R. (1964). Natural and cultural stratigraphy in the Birch Creek Valley of eastern Idaho, Birch Creek papers No. 2. Occasional papers of the Idaho Museum of Natural History, No. 14. Pocatello: Idaho State University.

Thomas, D.H. (1981). How to classify the projectile points from Monitor Valley, Nevada. Journal of California and Great Basin Anthropology, 3(1), 7-43.

Thomas, D.H., Davis, J.O., Grayson, D.K., Melhorn, W.N., Thomas, T., \& Trexler, D.T. (1983). The archaeology of Monitor Valley. 2: Gatecliff Shelter (Volume 59(1)). Anthropological Papers of the American Museum of Natural History. New York.

Tullis, J.A. (1995). Characteristics and origin of earth-mounds on the eastern Snake River Plain, Idaho. Unpublished M.A. thesis, Idaho State University, Pocatello.

Tuohy, D.R. (1980). Obsidian hydration dates for western Great Basin prehistory. In L.B. Harten, C.N. Warren \& D.R. Tuohy (Eds.), Anthropological papers in memory of Earl H. Swanson, Jr (pp.48-66). Special Publication of the Idaho Museum of Natural History. Pocatello: Idaho State University.

Waters, M.R. (1992). Principles of geoarchaeology: A North American perspective. Tucson: University of Arizona Press.

Waters, M.R. (1991). The geoarchaeology of gullies and arroyos in southern Arizona. Journal of Field Archaeology, 18(2), 141-159. 
Wigand, P. (1997). Pollen and macrofossil analysis of site 10MA143. Reno: Desert Research Institute.

Wingard, G. (1999). Carlon Village: Land, water, subsistence, and sedentism in the northern Great Basin. University of Oregon Anthropological Papers, No. 57. Eugene: Museum of Natural History and Department of Anthropology, University of Oregon.

Wriston, T.A. (2003). The Weed Lake Ditch site: An early Holocene occupation on the shore of pluvial Lake Malheur, Harney Basin, Oregon. Unpublished M.A. thesis, University of Nevada, Reno. 
TABLES (see attached)

\section{FIGURES}

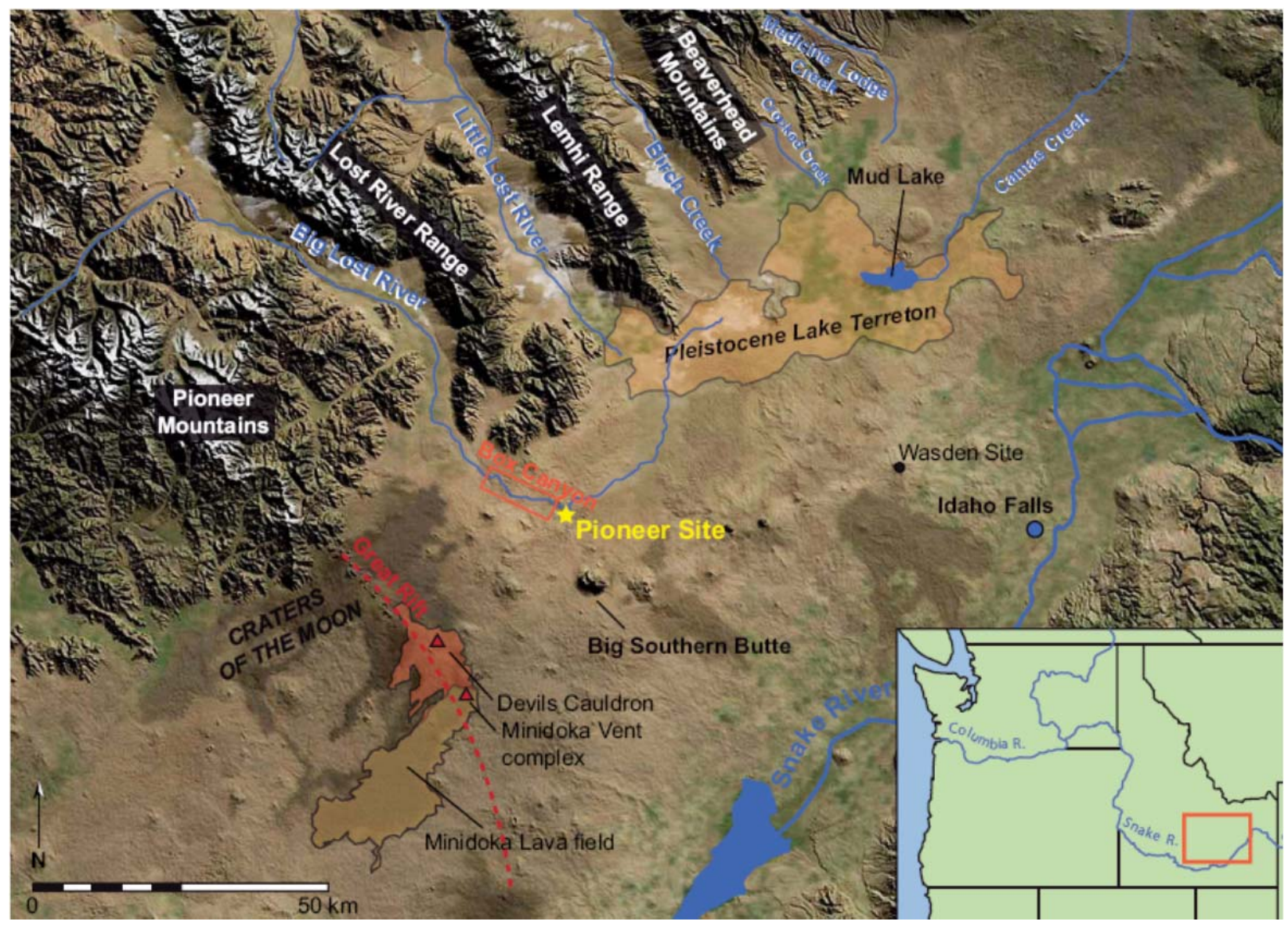

Figure 1. Location of the Pioneer site on the Big Lost River and surrounding area. 


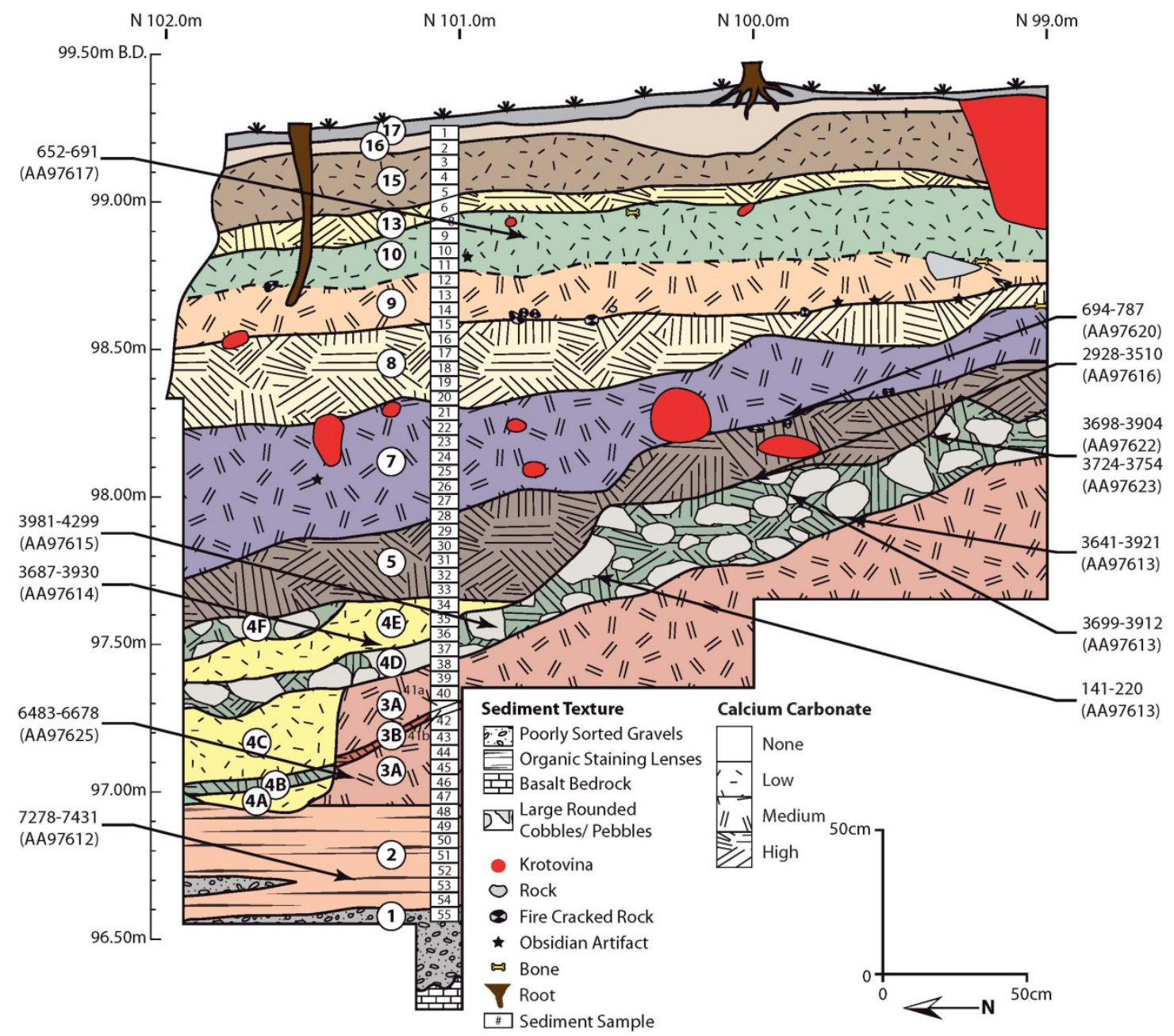

Figure 2. East Wall Profile of N99-N101, E42 (2011 Excavation) showing approximate locations of AMS dates in calibrated years BP. 


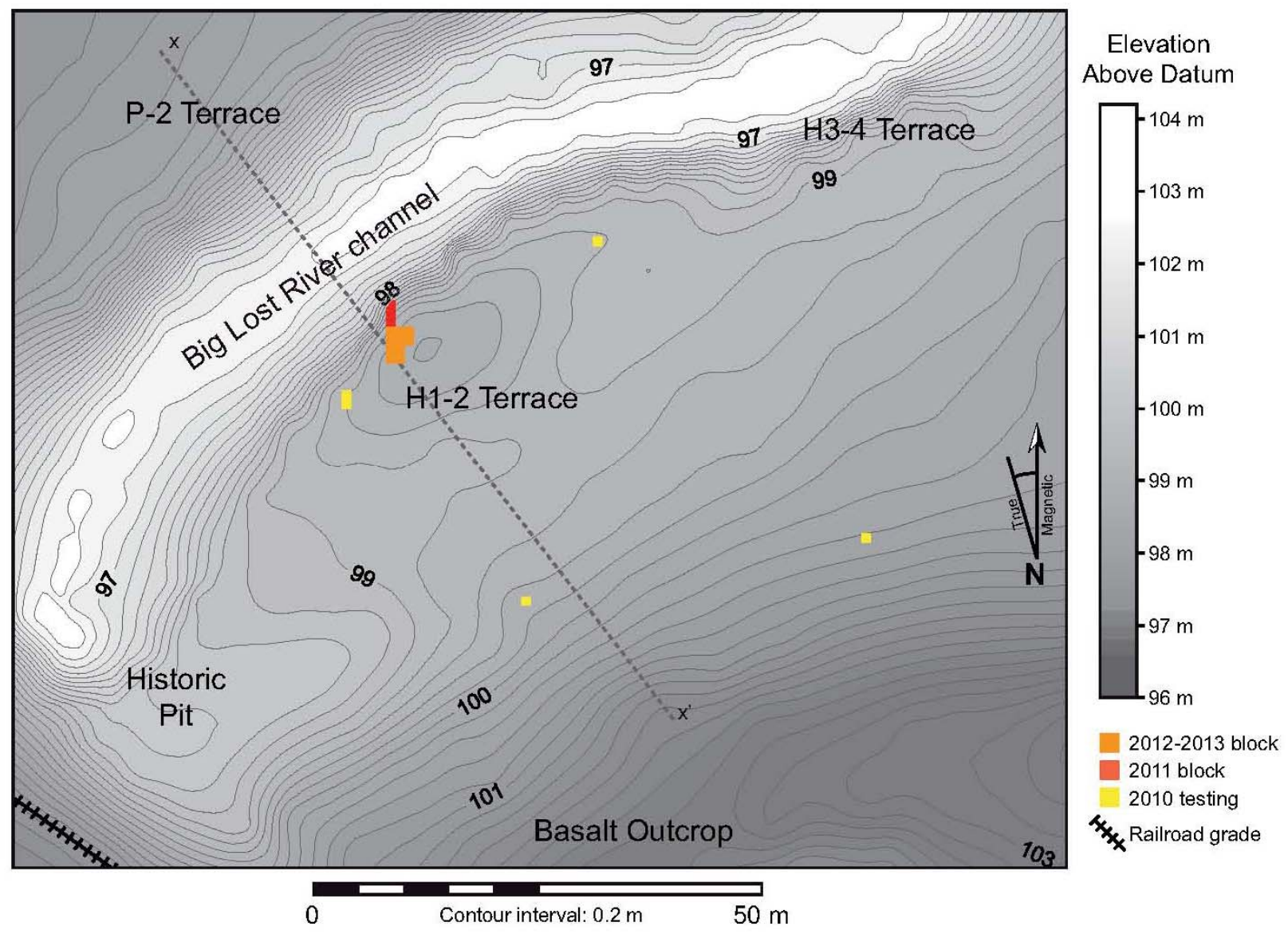

Figure 3. Topographic Map of Pioneer Site Excavation Block and Surrounding Terraces ( $\mathrm{x}-\mathrm{x}$ ' refers to cross-section in Figure 4). 


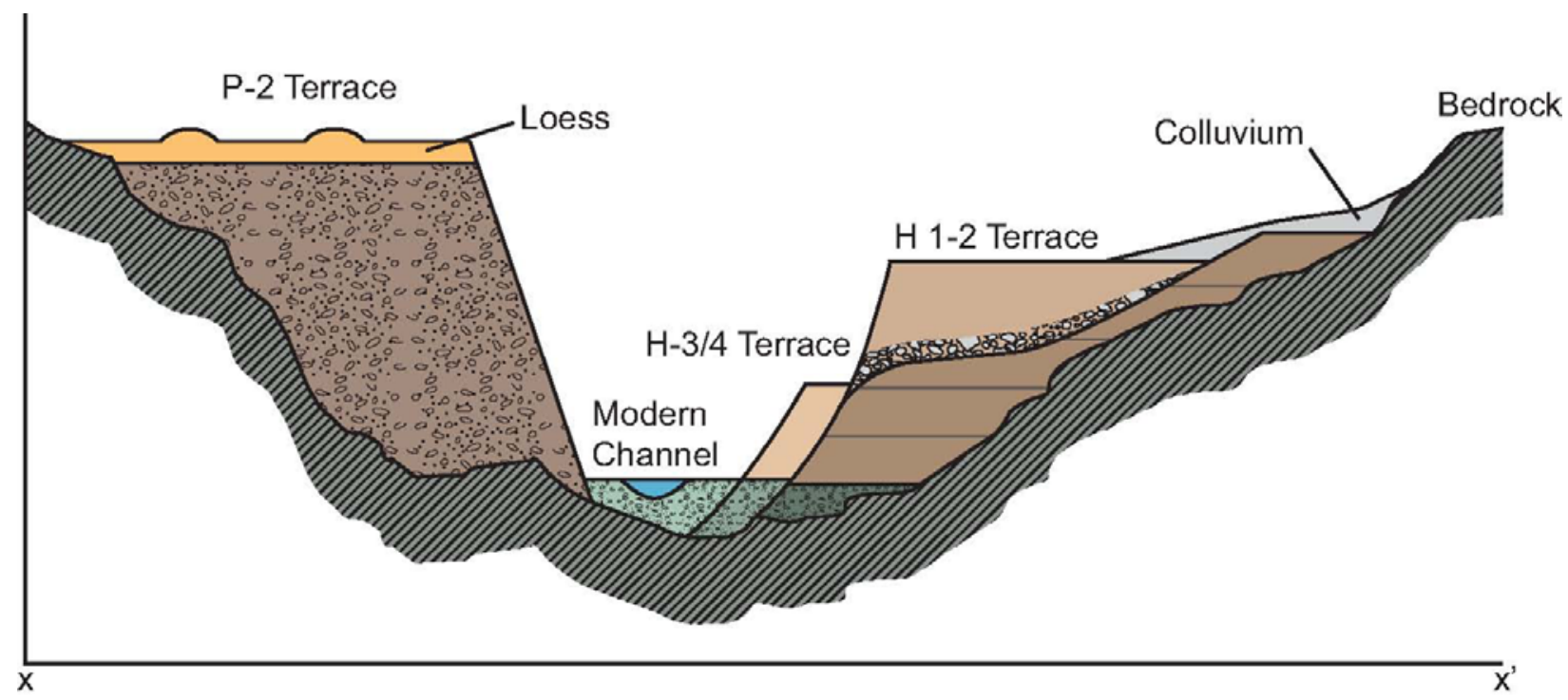

Figure 4. Representative Profile of the Big Lost River Terraces at Pioneer (not to scale) (x-x' shown in Figure 3).

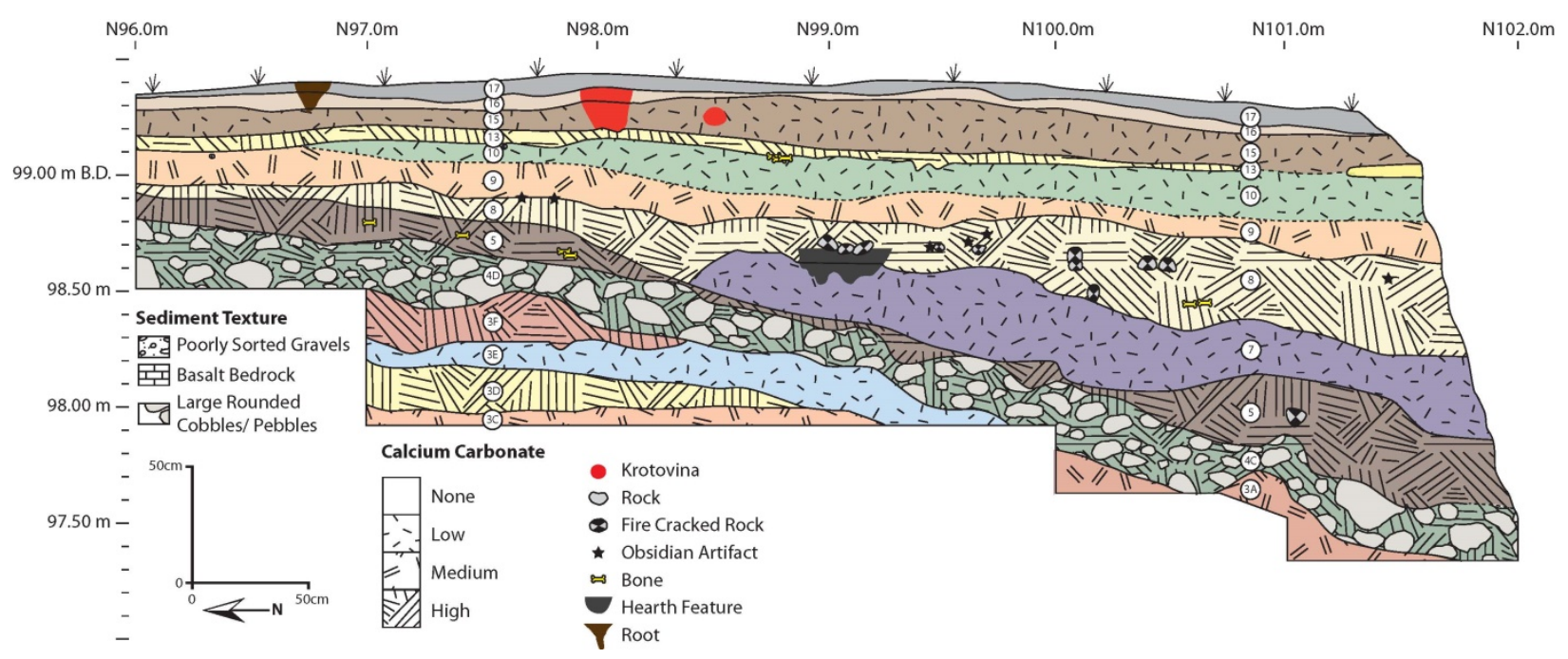

Figure 5 West Wall Profile of N96-N101, E42 (2011-2013 Excavation). 


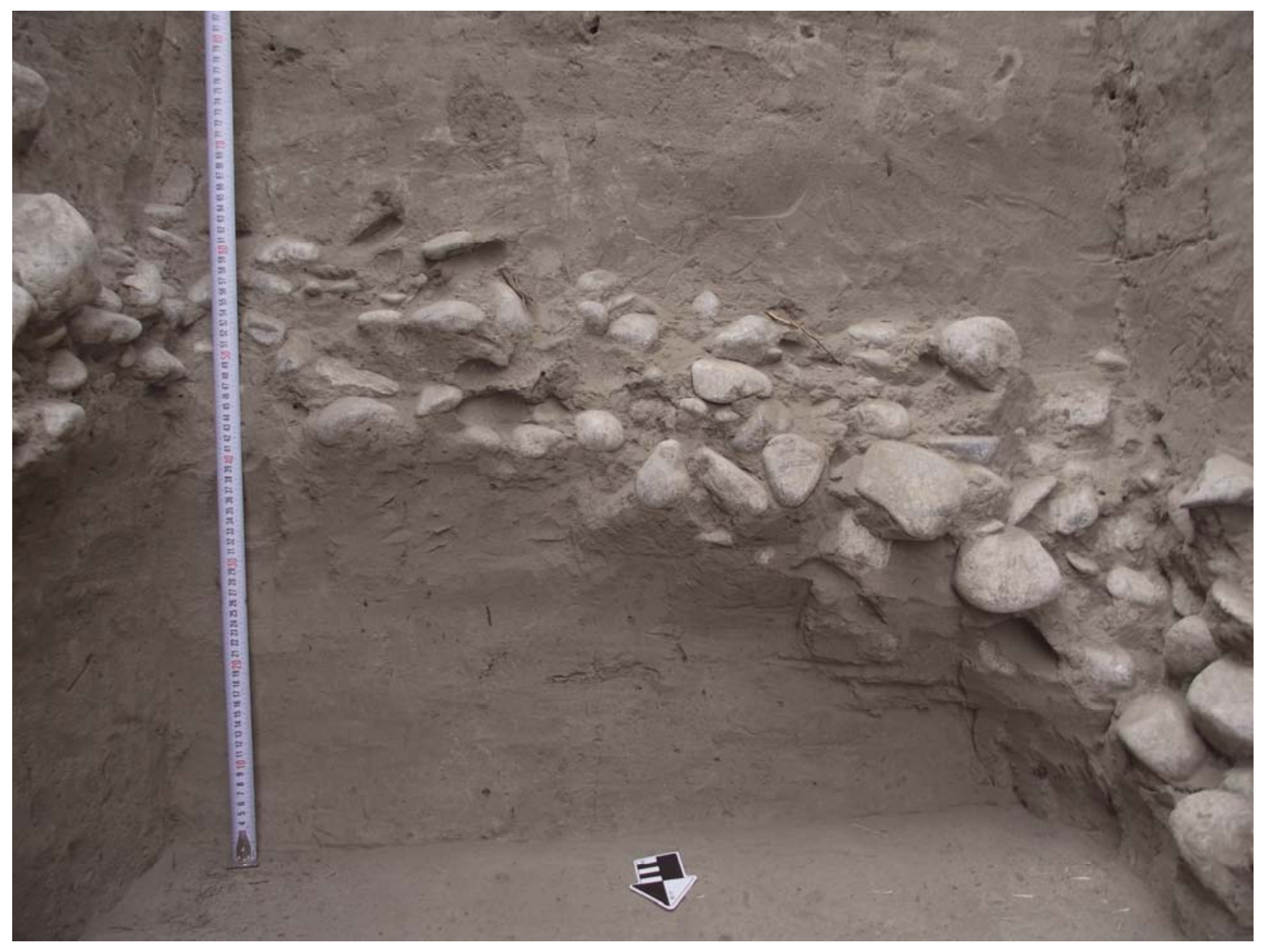

Figure 6. View of Strat 4D cobble layer in south wall of unit 99N E42. 


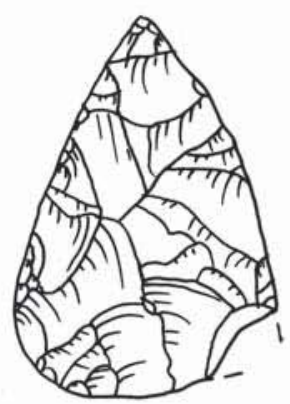

a

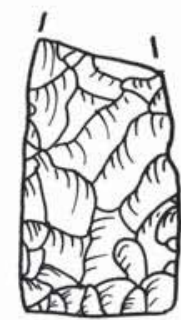

g

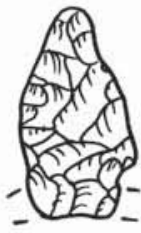

$\mathrm{n}$

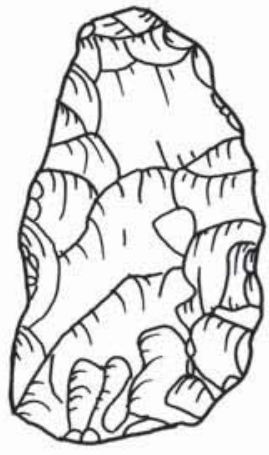

b

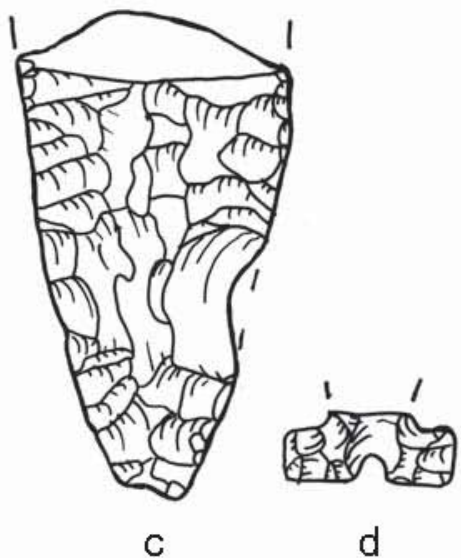

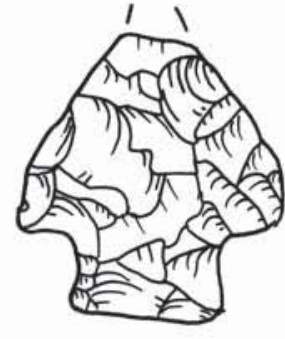

e
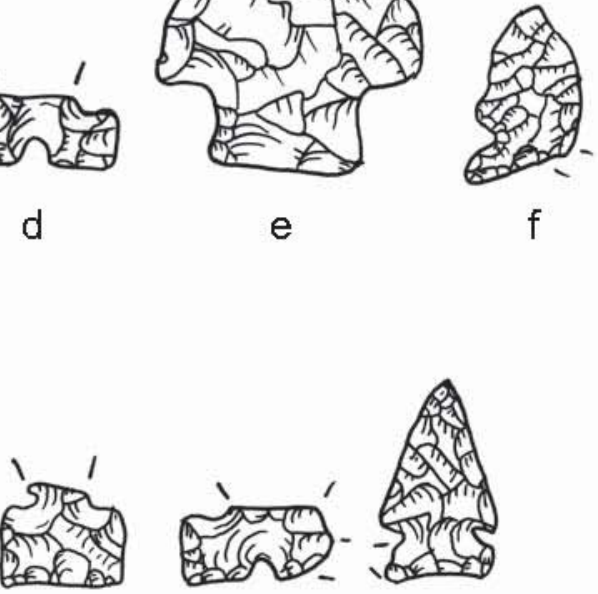

$\mathrm{k}$

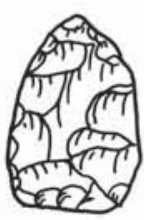

$r$

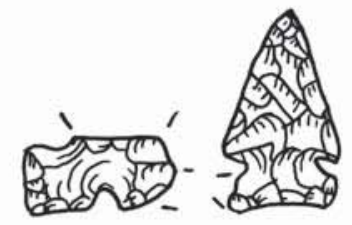

$\mathrm{m}$

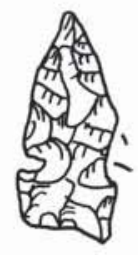

S

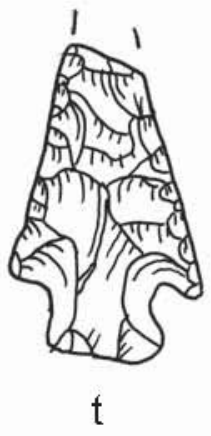

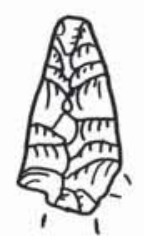

0

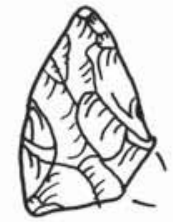

$\mathrm{p}$

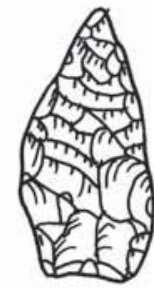

q

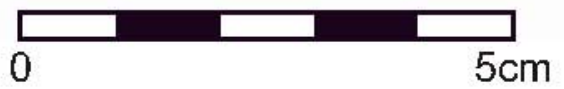

Figure 7. Diagnostic artifacts from Pioneer. a-b) Beaverhead preforms, stratum 4; c) Stemmed point preform, stratum 5; d) Desert Side-notched point, Sierra variety, stratum 6; e) Elko point, stratum 8; f) Avonlea point, strata 9-10; g-j) Cottonwood triangular points, strata 9-10; k) Desert Side-notched points, stratum 9-10;1) Desert Side-notched, Sierra variety, strata 9-10; m-o) Rosegate points, strata 9-10; p-r) Cottonwood triangular points, strata 13-17; s) Desert Sidenotched point, stratum 13-17; t) Elko point, stratum 13-17. 
Table 1. Radiocarbon dates from Ostenaa 2005 testing project (Ostenaa 2005: Table 2-2).

\begin{tabular}{|c|c|c|c|c|c|c|}
\hline $\begin{array}{l}\text { Trench } \\
\text { No. }\end{array}$ & $\begin{array}{l}\text { Sample } \\
\text { No. }\end{array}$ & $\begin{array}{l}\text { Sample } \\
\text { Depth }(\mathrm{cm})\end{array}$ & $\begin{array}{l}\text { Material } \\
\text { Dated }\end{array}$ & Lab No. & $\begin{array}{l}\text { 14C Age BP } \\
( \pm 1 \sigma)\end{array}$ & $\begin{array}{l}\text { Calibrated } \\
\text { Age BP }( \pm 2 \sigma)\end{array}$ \\
\hline & T4-20- & & & Beta- & & $630-600 ; 560-$ \\
\hline \multirow[t]{10}{*}{ T4 } & $1 \mathrm{AR}$ & $20-25$ & Artemisia charcoal & 174101 & $520 \pm 40$ & 510 \\
\hline & T4-20- & & & Beta- & & \\
\hline & $2 A R$ & $38-51$ & Artemisia charcoal & 174102 & $1070 \pm 40$ & $1060-930$ \\
\hline & T4-19- & & & Beta- & & \\
\hline & $1 \mathrm{AR}$ & $50-60$ & Artemisia charcoal & 174099 & $1130 \pm 40$ & $1160-950$ \\
\hline & T4-19- & & & Beta- & & \\
\hline & $1 \mathrm{CO}$ & $50-60$ & Conifer charcoal & 174100 & $1980 \pm 40$ & $2000-1860$ \\
\hline & T4-19- & & Chrysothamnus & Beta- & & \\
\hline & $3 \mathrm{CH}$ & $140-155$ & charcoal & 172812 & $6330 \pm 40$ & $7320-7200$ \\
\hline & & & & Beta- & & \\
\hline \multirow[t]{4}{*}{ T5 } & T5-0-1AR & $22-32$ & Artemisia charcoal & 174103 & $780 \pm 40$ & $760-660$ \\
\hline & & & & Beta- & & \\
\hline & T5-0-2CO & $110-132$ & Conifer charcoal & 174104 & $1880 \pm 40$ & $1900-1720$ \\
\hline & & & & Beta- & & \\
\hline \multirow[t]{13}{*}{ T6 } & T6-4-1SA & $12-25$ & Salicaceae charcoal & 174106 & $630 \pm 40$ & $660-540$ \\
\hline & & & & Beta- & & \\
\hline & T6-4-1AR & $12-25$ & Artemisia charcoal & 174105 & $830 \pm 40$ & $790-680$ \\
\hline & & & & Beta- & & \\
\hline & T6-6-1YS & $95-105$ & snail shell & 183387 & $10390 \pm 50$ & $12800-11940$ \\
\hline & T6-4- & & & Beta- & & \\
\hline & $2 \mathrm{MIX}$ & $103-121$ & charcoal fragments & 172813 & $3210 \pm 40$ & $3480-3360$ \\
\hline & T6-20- & & & Beta- & & \\
\hline & $2 \mathrm{MIX}$ & $110-140$ & charcoal fragments & 183388 & $2710 \pm 40$ & $2870-2760$ \\
\hline & T6-68- & & & Beta- & & \\
\hline & $1 \mathrm{AR}$ & $30-40$ & Artemisia charcoal & 174107 & $620 \pm 40$ & $660-540$ \\
\hline & & & & & & $290-250 ; 230-$ \\
\hline & T9-32- & & & Beta- & & 130 \\
\hline \multirow[t]{5}{*}{ T9 } & $1 \mathrm{PO}$ & $35-45$ & Populus charcoal & 183391 & $170 \pm 40$ & $110-70 ; 30-0$ \\
\hline & T9-32- & & Chrysothamnus & Beta- & & \\
\hline & $2 \mathrm{CM}$ & $105-115$ & charcoal & 183392 & $130 \pm 40$ & $290-0$ \\
\hline & & & & Beta- & & \\
\hline & T9-2-2AR & $105-115$ & Artemisia charcoal & 183389 & $2610 \pm 40$ & $2730-2780$ \\
\hline
\end{tabular}

